\section{NEWXYSBKHOOL}

Faculty Scholarship digitalcommons.nyls.edu

Articles \& Chapters

$3-1-2003$

\title{
Racial Profiling and Terrorism
}

Stephen J. Ellmann

New York Law School, stephen.ellmann@nyls.edu

Follow this and additional works at: http://digitalcommons.nyls.edu/fac_articles_chapters

\section{Recommended Citation}

46 N.Y.L. Sch. L. Rev. 3-4

This Article is brought to you for free and open access by the Faculty Scholarship at DigitalCommons@NYLS. It has been accepted for inclusion in Articles \& Chapters by an authorized administrator of DigitalCommons@NYLS. 


\title{
RACIAL PROFILING AND TERRORISM
}

\author{
Stephen J. Ellmann*
}

\section{The Issue: \\ Does Terrorism Change the Rights and Wrongs of Profiling?}

September 11 has forced us to look again at who we are. We have re-encountered our own society, as we came to grips with the deaths of thousands only a few blocks from our law school. We have re-encountered the world, its intractable conflicts and the rage and ruthlessness those conflicts sometimes generate. We have sought to reaffirm, as lawyers, the highest traditions of the bar, in public service and human connection. It is the special responsibility of academics, however, to ask as well whether any of the ideas to which we have long been committed now must be reassessed because the world is different than we thought. In doing this, we must beware of panic and over-reaction, particularly now that the most immediate crisis is past. But at the same time we should not shrink from this task; what may seem to outsiders to be a "defense mechanism" may in fact be "self-defense." In this spirit, I address here the question of whether there are any circumstances in which racial profiling, or profiling on other similar grounds, is justifiable as a response to terrorism.

We know that it must not be a crime to be found "driving while black." We know that it is wrong for a town investigating a violent crime allegedly committed by a young black man to seek to question every black male student at the local college, and many or most black

* Associate Dean for Faculty Development and Professor of Law, New York Law School. I appreciate the comments of Robert Blecker, Gene Cerruti, Terry Cone, Sam Gross, Rick Matasar, Beth Noveck, Michael Perlin, Louis Raveson, Nancy Rosenbloom, Sadiq Reza, David Schoenbrod, Geoffrey Stone, Leti Volpp, and Tom Whitson on the issues of this article, as well as the insightful comments and questions from members of the audience at the Faculty Presentation Day evening panel at which this piece was first presented, and from colleagues at a subsequent NYLS faculty workshop. I also thank Michelle Datiles for her excellent research assistance. Responsibility for the conclusions is mine alone.

1. Danger in some ways worsens our judgment, but in one way it certainly can have the opposite effect: it concentrates our minds on risk, and so can make us better at deciding what risk requires than we would be if we entertained the same question in less anxious times. This essay attempts to look at the risks we face, and what steps those risks do and do not justify. 
residents of the local town. ${ }^{2}$ We know that people of every race should be free to walk in every neighborhood of the country without being quizzed by the police about their reasons for being there - even if all the residents of the neighborhood are of another race. ${ }^{3}$

We know, in short, that racial profiling-that is, deploying the apparatus of law enforcement from brief interrogations on the street to searches, seizures and arrests - on the basis of generalizations about race is, ordinarily, a violation of fundamental principles of the equal protection of the laws. ${ }^{4}$ The same would be true of taking such steps

2. But see Brown v. Oneonta, 221 F.3d 329, 333-34 (2d Cir. 1999), cert. denied, 122 S.Ct. 44 (2001).

3. Cf. Kolender v. Lawson, 461 U.S. 352, 353 (1983) (striking down, as unconstitutionally vague, a statute "requir[ing] persons who loiter or wander on the streets to provide a 'credible and reliable' identification and to account for their presence"); Brown v. Texas, 443 U.S. 47, 53 (1979) (holding unconstitutional a Texas statute permitting police "to detain [a person] and require him to identify himself" when "the officers lacked any reasonable suspicion to believe [he] was engaged or had engaged in criminal conduct"). According to Samuel R. Gross and Debra Livingston, "[m]ost courts . . . have held that . . . being racially 'out of place' does not create a reasonable suspicion of criminal activity." Samuel R. Gross \& Debra Livingston, Racial Profiling Under Attack, 102 Colum. L. Rev. 1413, 1432-33 (2002).

4. Implicit in this definition is a distinction between law enforcement actions based on generalizations about race - propositions that particular racial groups are more or less likely to commit crimes - and other law enforcement steps based on information about particular suspects' identifying descriptions. See Gross \& Livingston, supra note 3 , at 1415 . To act on the basis of a particular suspect's description as belonging to a given race is certainly to take race into account, but it is not to take generalizations about race into account.

This distinction, however, is more elusive than might at first appear. Suppose a suspect description consists of nothing more than race and gender (e.g., "Asian male"). Such a description on its face identifies a demographic group rather than an individual, unless the context makes its meaning much more specific (for example, if the suspect is identified as "the only white guy in the room"). If police then initiate indiscriminate stops and searches of members of that demographic group, I would characterize their action as racial (and, here, gender) profiling, based on an implicit generalization that any member of the demographic group in question is likely enough to have committed the crime to be a proper subject of scrutiny. (On this point of classification, I differ with Gross \& Livingston, who would not call such action profiling; they would consider it "disturbing," however, see id. at 1435-36, and they emphasize that "it is a mistake to focus excessively on labels." Id. at 1416.)

As in other constitutional contexts, the test of violation of the general rule against profiling should not be whether race (or similar factors) were the only considerations triggering the law enforcement action, but whether these factors were a "but for" cause of the government's acts. See Mt. Healthy City School Dist. v. Doyle, 429 U.S. 274, 285-87 (1977) (adopting "but for" test in First Amendment context). For a case seemingly requiring that race be the "sole motive," see United States v. Avery, 137 F.3d 343 (6th Cir. 1997). Avery, however, has been circumscribed by Farm Labor Organizing Committee v. 
simply on the basis of religion, though for some decades the idea that anyone would want to "profile" on the basis of religion would have seemed quite odd in the United States. Profiling among United States citizens on the basis of their national origin is essentially a form of profiling on the basis of race or ethnicity, and equally unacceptable. ${ }^{5}$ So too, profiling on the sole basis of gender must, in general, be unconstitutional. ${ }^{6}$ And the same must be true of profiling based on some or all of these factors combined. ${ }^{7}$

Constitutional law on discrimination suggests that this prohibition on racial profiling (or profiling on other comparably unacceptable grounds) must be quite strict. ${ }^{8}$ It is important to recognize, as well, that this prohibition does not rest on an assumption that there is never any basis in fact for the profiler's stereotypes. Consider two cases from somewhat different equal protection contexts. In Craig $v$. Boren the Supreme Court first established the rule of intermediate scrutiny for gender discrimination. ${ }^{9}$ Statistics presented in that case arguably demonstrated that young men were much more likely to get arrested

Ohio State Highway Patrol, 308 F.2d 523, 538 (6th Cir. 2002), which characterized the "'sole motive' requirement ... . [as] an anomaly in equal protection law ... . [which] should not be applied outside the narrow factual context of purely consensual encounters." Although "but for" causation should be sufficient, it must be recognized that if law enforcement officers act largely on the basis of individualized considerations, then - even if racial generalizations do play a "but for" part - their conduct is less like profiling and more like the use of suspect descriptions. Clearly police conduct falls on a spectrum rather than being, unmistakably, either profiling or not profiling; my focus in this essay, however, is on those steps that are largely guided by generalizations rather than individualized inquiry.

5. Profiling on the basis of alienage, however, is another matter. While discrimination on the basis of alienage by states and localities has been subjected to strict scrutiny, Sugarman v. Dougall, 413 U.S. 634, 642 (1973), the federal government has much more leeway in this field, see Mathews v. Diaz, 426 U.S. 67, 77-87 (1976). See infra note 17.

6. This is so despite the fact that men commit far more crimes than women. William J. Stuntz, Local Policing After the Terror, 111 Yale L.J. 2137, 2178 (2002). The insistence on gender-free judgment built into the "exceedingly persuasive justification" test must generally preclude profiling all men as criminals based on the crimes some men commit. See United States v. Virginia, 518 U.S. 515 (1996), and see infra text accompanying notes 9-13.

7. Profiling on the basis of age presumably can pass constitutional muster more easily, since under current doctrine age discrimination is subject only to rational relationship scrutiny. Kimel v. Florida Bd. of Regents, 528 U.S. 62, 83-84 (2000).

8. In this essay I will often refer simply to racial profiling, which surely is the most egregious of these forms of discrimination. These references, however, are meant as shorthand for profiling on the grounds of race or other, similarly unacceptable, factors.

9. Craig v. Boren, 429 U.S. 190 (1976). 
for drunk driving than young women were — though neither men nor women were tremendously likely to get arrested for this reason. ${ }^{10} \mathrm{On}$ that basis, the state of Colorado had permitted women to buy nearbeer (3.2\%-alcohol beer) at a younger age than men could. This was a silly statute, but the Court's reasoning is still important; it considered the idea of legislating to disfavor men based on these sociological generalizations "inevitably in tension with the normative philosophy that underlies the Equal Protection Clause." 11 In somewhat the same way, the Supreme Court in J.E.B. v. Alabama ex rel. T.B. said that lawyers could not exercise peremptory challenges against jurors on the basis of gender; ${ }^{12}$ Justice O'Connor wrote in a separate opinion that this had to be the rule for the government (though not, in her view, for private litigants) even if in fact - as surely is so - a juror's sex can sometimes make a difference to how she or he sees the case. ${ }^{13}$ Stereotypes sometimes have some truth to them; what stereotypes do not have, under our law, is a legitimate bearing on the question of how government should treat an individual person, whatever groups he or she belongs to. Too many innocent people are harmed by stereotyping, and too much damage is done to the ideal of equal justice under the law, for it to be acceptable as a tool of domestic law enforcement, even if it turns out to be of some statistical value. ${ }^{14}$

All of which leads to the very unpleasant question of whether terrorism calls for exceptions to this rule. My focus is not on military operations $^{15}$ or foreign surveillance ${ }^{16}$ or even the enforcement of

10. Id. at 201 .

11. Id. at 204 .

12. J.E.B. v. Alabama ex rel. T.B., 511 U.S. 127 (1994).

13. Id. at 148-50 (O'Connor, J., concurring).

14. Whether it is of any statistical value in domestic contexts is a contested matter, which I discuss below. See infra notes 67-78.

15. Justice Jackson wrote in his dissent in Korematsu that "[i]t would be impracticable and dangerous idealism to expect or insist that each specific military command in an area of probable operations will conform to conventional tests of constitutionality. When an area is so beset that it must be put under military control at all, the paramount consideration is that its measures be successful, rather than legal." Korematsu v. United States, 323 U.S. 214, 244 (1944) (Jackson, J., dissenting). Soldiers must make life-anddeath decisions in an instant, and some of these must involve profiling. The classic World War II stories of troops identifying German spies by testing their knowledge of the Brooklyn Dodgers offer one illustration. The racial epithets of that and other wars demonstrate that even on the battlefield, such stereotyping can reflect mere prejudice.

16. Here, as in the context of immigration law, see infra note 17. I do not mean to examine, or assume the validity of, all possible forms of profiling. Some such steps, 


\section{immigration and customs laws at our borders, ${ }^{17}$ though in each of}

however, seem plainly appropriate. Consider the following, probably not hypothetical, example:

* The government conducts surveillance of electronic communications. It programs the computers that screen the contents of these communications to pay special attention to all messages sent in Arabic, Pashtun and other languages known to be used by Al Qaeda.

In actuality, it appears that prior to September 11 we were in effect following the opposite policy: because our intelligence agencies had so few speakers of languages that potential terrorists might be speaking, we were paying less attention to messages in these languages than sheer random selection would have generated. See Joy Kreeft Peyton \& Donald A. Ranard, We Can't Squander Language Skills, at http://www. international.ucla.edu/lrp/news/joypeyton.html (last visited Aug. 1, 2002) ("Our foreign language deficiency is particularly acute in the uncommonly taught languages of Asia, Africa and the Middle East.") Now, presumably, we are doing everything we can to correct this mistake, and to single out messages in these languages for attention. Since the speakers of these languages are, disproportionately, members of particular ethnic groups and citizens of particular nations, it is quite plausible to describe this new attentiveness as a discriminatory security measure. But it is hard to imagine how we can improve our electronic surveillance if we do not increase the attention we pay to messages in these languages - and so the "necessity" for this step seems clear. At the same time, and for the same reason, it is implausible to see this step as profoundly stigmatizing to, say, Pashtuns. Members of this ethnic group have been central to the Taliban, and the Taliban has been allied with al Qaeda; to state these propositions is not to stigmatize but simply to report, just as it would not have been stigmatizing to report in World War II that we were at war with Japan. To deal with one's enemies one must be able to understand them, and paying attention to messages in Pashtun is not an assertion that all Pashtun are enemies but only that some have been and likely still are. Moreover, even though it is not illogical to describe a focus on Pashtun-language messages as a form of national-origin or ethnic discrimination, there is no indication that the underlying motivation for that discrimination is invidious stereotyping rather than practical response to real threats. Finally, and somewhat paradoxically, the stigmatizing effect of this program is lessened because it is not public. It is paradoxical to find discrimination less troubling because it is covert, since often the worst discrimination is the hidden, but deliberate, mistreatment. But here the reason for hiding the discrimination is not in order to get away with discrimination, but rather to maintain secrecy about security measures in order to maintain their efficacy. When secrecy has a legitimate justification, as here, the conduct kept secret can be less constitutionally troublesome than more public discrimination by the government of us all.

17. In the context of immigration law, "Congress regularly makes rules that would be unacceptable if applied to citizens." Mathews v. Diaz, 426 U.S. 67, 80 (1976). Notably, distinctions are regularly made on the basis of the non-citizen's country of origin. To take a quite innocuous example, citizens of some countries can enter the United States without a visa; citizens of most nations, however, must get a visa before they travel here. Council on Foreign Relations, Terrorism: $Q \mathcal{E} A-$ Immigration ("Citizens of some Western countries and other countries with histories of respecting U.S. immigration policies can travel to the United States without first obtaining visas.") available at http:/ /www.terrorismanswers.com/security/ins_print.html (last visited Sept. 3, 2002).

There are, of course, a number of anti-terrorism steps that might be taken, or are already underway, at our borders. One recent proposal is to impose "fingerprinting, photographing, and registration requirements" on citizens of countries from which we see a special danger of terrorism. See U.S. Department of Justice, National Security Entry- 
Exit Registration System, June 5, 2002, at 2, available at http://www.usdoj.gov/ag/ speeches/2002/natlsecentryexittrackingsys.htm (last visited Sept. 3, 2002) ("This initiative will require fingerprinting, photographing, and registration requirements on [sic] the following: (1) All nationals of Iran, Iraq, Libya, Sudan and Syria (2) Certain nationals of other countries whom the State Department and the INS determine to be an elevated national security risk (3) Aliens identified by INS inspectors at point of entry upon specific criteria to be established by the Department of Justice."); Seattle PostIntelligencer News Services, Ashcroft Proposes New Guidelines for Foreigners in U.S.: Visitors Would Be Required to Register with Government (June 6, 2002), available at http:// seattlepi.nwsource.com/national/73466_visa06.shtml (last visited Aug. 2, 2002) ("Other government officials said men 18 to 35 years of age from about 20 largely Muslim and Middle Eastern nations, including key allies such as Saudi Arabia and Egypt, would make up the bulk of those" covered). This program applies "[e]ven if a man does not live in one of those countries," if "he or a close relative was born in one of them," and it has reportedly caused "interminable" delays and a backlog of 100,000 applications. "[V]ery few visas have been issued to men in this category." Raymond Bonner, Immigration: New Policy Delays Visas For Specified Muslim Men, N.Y. Times, Sept. 10, 2002, at A12. Another is the planned Interagency Panel on Advancing Science and Security, which will limit student visas based on, among other things, the sensitivity of the information the student plans to study and whether the applicant is a citizen of a nation "determined as suspicious or dangerous." See University of Pennsylvania Almanac, Government Affairs Update (May 28, 2002), available at www.upenn.edu/almanac/ $\mathrm{v} 48 / \mathrm{n} 35 / \mathrm{GA}$-Update.html (last visited Sept. 3, 2002). Yet another idea might be to profile goods imported from particular countries; from the vast number of cargo "containers" now arriving every day, most of which we do not have the resources to search, we might target those from particular countries. See Bill Keller, Nuclear Nightmare, N.Y. Times, May 26, 2002, $\S 6$, at 22 ("Two thousand containers enter America every hour.... Fewer than 2 percent are cracked open for inspection, and the great majority never pass through an X-ray machine.").

Broad as the federal "plenary power" over immigration is, Fiallo v. Bell, 430 U.S. 787, 792 (1976), I do not assume that all forms of profiling at the border would be constitutional under current doctrine (or that that doctrine is necessarily sound), or that these steps would be effective or wise. Cf. David Cole, Enemy Aliens, 54 STAN. L. Rev. 953 (2002) (criticizing our tendency to sacrifice noncitizens' rights in the name of security). For an example of what appears to be misuse of this power, see Dan Chapman, War on Terrorism: Yemeni Passenger Claims Racial Profiling at Hartsfield; GSU Student Detained Under Nerw U.S. Policy, Atlanta Journal-Const., June 14, 2002, at 12A. This article reports a Yemeni student's contention that she was detained for an hour, searched and questioned. According to the article, "Immigration and customs officers . . . are simply following a directive from Washington, issued last Friday [June 7, 2002], which compels them to more readily question Yemenis and search their baggage. . . U.S. officials confirmed this week that an apartment in New York that once was occupied by Yemeni nationals contained bomb-making equipment." If this account is correct, it describes particularly crude and questionable profiling, even in the context of the broad powers the government wields at its borders. A chilling concurrent development has been the passage of legislation limiting the extent to which law enforcement officials can be sued for abuse of such authority. See Trade Act of 2002, H.R. 3009, $\$ 341$ (a); American Civil Liberties Union, Trade Bill Lets Customs Service Use Racial Profiling; Makes it Next to Impossible to Sue Agents Who Abuse Traveling Public (Aug. 1, 2002), available at 
these contexts profiling is, or may well be, underway. Important as those contexts are, I concentrate here on domestic law enforcement. Domestic law enforcement is the setting in which a national debate about racial profiling has already taken place, and I want to explore whether the consensus that racial profiling is wrong in our neighborhoods and on our highways holds true when the target is terrorism rather than ordinary crime. ${ }^{18}$ In addition, domestic law enforcement involves the exercise of state power under the fullest constitutional restrictions - those applicable to the government's treatment of citizens and of noncitizens already in the country. Whatever the exact dimensions of the plenary power over immigration, ${ }^{19}$ it is clear that those subject to it do not enjoy the same constitutional protection as those, citizens and noncitizens, who are within our borders. ${ }^{20}$ I mean to ask, in other words, whether the fullest constraints of the constitution do always forbid racial profiling as a response to terrorism. ${ }^{21}$ This is also to ask whether terrorism justifies discrimination among those people, citizens above all, who are most fully members of our national community.

http://www.aclu.org/news/2002/n080102b.html (last visited Sept. 12, 2002) (criticizing provision of Andean Trade Preference Expansion Act, passed by both Houses of Congress in July - August 2002).

18. Samuel Gross and Debra Livingston begin their recent essay on profiling and terrorism with the observation that "We had just reached a consensus on racial profiling. By September 10, 2001, virtually everyone, from Jesse Jackson to Al Gore to George W. Bush to John Ashcroft, agreed that racial profiling was very bad." Gross \& Livingston, supra note 3 , at 1413 .

19. See, e.g., Fiallo v. Bell, 430 U.S. 787, 792 (1977) ("This Court has repeatedly emphasized that 'over no conceivable subject is the legislative power of Congress more complete than it is over' the admission of aliens.").

20. The Supreme Court has emphasized that the federal immigration power is more circumscribed "once an alien enters the country." Zadvydas v. Davis, 533 U.S. 678, 693 (2001). In this essay it is unnecessary for me to address the question of whether, even in domestic law enforcement contexts, foreigners in this country illegally enjoy full constitutional protection, and in particular full Fourth Amendment protection from searches and seizures. See T. Alexander Aleinikoff, Semblances of Sovereignty: The Constitution, the State, and American Citizenship 171, $290-91$ n.118 (2002).

21. As will be seen, I include in the category of "domestic law enforcement" the programs in which the government has interviewed thousands of non-immigrant visa holders, largely from the Middle East, concerning any knowledge they might have of terrorist activities. See infra text accompanying notes 129-53. There are also certain programs that might be seen as intermediate between border control and domestic law enforcement, involving the enforcement of immigration law on an ongoing basis, and I will briefly discuss these as well. See infra note 157 . 
Let me begin by restating this same question in the language of constitutional doctrine. The question then is: is profiling, on the basis of race and/or religion, narrowly tailored or necessary to a compelling governmental interest - because under standard formulations, race discrimination or religious discrimination are not unconstitutional per $s e$ but only if the justifications for them cannot stand up under this kind of strict scrutiny. ${ }^{22}$ There is in fact a Supreme Court case, Lee v. Washington, ${ }^{23}$ decided well after Brown v. Board of Education ${ }^{24}$ had sounded the death knell for de jure racial segregation in the United States, in which the Court seemed to imply that racial segregation in a prison in response to particular "necessities of prison security and discipline" could be constitutional - not as a normal governmental step, but as what we might call an emergency response to, say, race riots in the prison. ${ }^{25}$ Racial profiling, this old case suggests, is not absolutely and automatically forbidden. But as Brown and many other cases confirm, it is and should be extremely hard to justify.

Extremely hard - but perhaps not impossible. Indeed, in the context of border patrols it has been accepted by the Supreme Court,

22. See, e.g., Adarand Constructors, Inc. v. Pena, 515 U.S. 200, 227 (1995). Little turns on whether "necessity" or "close tailoring" is the formula applied, for it seems implausible that a step could be considered "necessary" and yet not also be accepted as being as "closely tailored" as could be required under the circumstances. The focus on "close tailoring," much the more common formula in recent equal protection cases, certainly reminds us that precision is an important element of necessity, see Wygant v. Jackson Bd. of Educ., 476 U.S. 267, 280 (1986) (plurality opinion of Powell, J.), but it does not, I believe, require complete precision when something less than complete precision is what is genuinely necessary.

23. Lee v. Washington, 390 U.S. 333 (1968).

24. Brown v. Bd. of Educ., 347 U.S. 483 (1954).

25. The per curiam decision rejected the state's contention "that the specific orders directing desegregation of prisons and jails make no allowance for the necessities of prison security and discipline" by saying that it did not so read the lower court's decision. Lee v. Washington, 390 U.S. 333, 333-34 (1968). The lower court decision, written by a judge who played a crucial role in the desegregation of Alabama, Frank M. Johnson, Jr., had in fact stated that "there is merit in the contention that in some isolated instances prison security and discipline necessitates segregation of the races for a limited period." Washington v. Lee, 263 F. Supp. 327, 331 (M.D. Ala. 1966). In the Supreme Court, three justices were more explicit in affirming a proposition they felt was "left to be gathered only by implication from the Court's opinions," namely that "prison authorities have the right, acting in good faith and in particularized circumstances, to take into account racial tensions in maintaining security, discipline, and good order in prisons and jails.” Lee v. Washington, 390 U.S. at 334 (Black, Harlan and Stewart, IJ., concurring). 
under the rubric of the Fourth Amendment. ${ }^{26}$ Employing the language of the strict scrutiny formula, we can begin with the question of whether a "compelling governmental interest" justifies taking such steps. Now, few people have ever doubted that ordinary law enforcement - the day-to-day efforts by the police to prevent murders, rapes and other normal perils of our lives from taking place - represents a "compelling governmental interest." ${ }^{27}$ But the strict scrutiny formula appears to be a balancing formula, and if we take this seriously then we should surely say that preventing terrorism presents an especially compelling governmental interest. ${ }^{28}$ The reasons for saying this don't need much elaboration, here, half a mile from what was the site of the World Trade Center. Terrorism is a danger to huge numbers of people, and perhaps to the nation itself, in a way that each individual crime of violence can hardly ever be. ${ }^{29}$

But the intensity of this governmental interest is not simply a matter of logic or popular sentiment. We are at war against terrorists and

26. In United States v. Brignoni-Ponce, 422 U.S. 873 (1975), the Court held that roving immigration patrol stops away from the border had to be based on "specific articulable facts . . . that reasonably warrant suspicion," $i d$. at 884 . In that calculus, the court said, "Mexican appearance" is not sufficient by itself, but it is "a relevant factor." Id. at 886-87. (The Ninth Circuit recently characterized the Court's comments about Mexican appearance as dictum and declined to follow them, in United States v. Montero-Camargo, 208 F.3d 1122, 1131-35 (9th Cir. 2000) (en banc) cert. denied sub nom. Sanchez-Guillen v. United States, 531 U.S. 889 (2000).) The following year, in United States v. Martinez-Fuerte, 428 U.S. 543 (1976), the Court decided that Border Patrol stops at permanent checkpoints, even away from the border, did not require "any individualized suspicion," $i d$. at 562, and that "even if it be assumed that such referrals are made largely on the basis of apparent Mexican ancestry, we perceive no constitutional violation." Id. at 563 (footnote omitted).

27. This must be so, even though the Supreme Court has apparently never said it (and even if saying it would inject serious complications into equal protection doctrine). See R. Richard Banks, Race-Based Suspect Selection and Colorblind Equal Protection Doctrine and Discourse, 48 UCLA L. REv. 1075, 1119 (2001). If enforcement of laws against serious crimes is not a compelling governmental interest, what can justify the massive deprivations of liberty that we impose as punishments?

28. William Stuntz surveys the ebb and flow of constitutional protections in criminal procedure and concludes that "[c]ourts are likely to respond to that pressure [to adapt the law to combat terrorism] in the same manner [as they have responded to pressure "in times of across-the-board rises in crime"] - by giving police more power. The fact of such a response is both proper and, at least given recent practice, normal." Stuntz, supra note 6 , at 2160 .

29. The most comparable threats in day-to-day life are probably those found in situations of pervasive crime, such as the gang domination of Chicago neighborhoods that prompted that city to enact an anti-loitering ordinance which the Supreme Court subsequently found unconstitutional. City of Chicago v. Morales, 527 U.S. 41 (1999). 
their allies who attacked us on September $11 .^{30}$ Assuming (as I do) that the war is constitutional even though it has never been formally declared, and even though it is not a war against any nation (at least since the success of our military effort in Afghanistan), it reflects a national judgment that a particular group of people represents so grave a risk to us that we must commit the nation to finding and killing them if they do not surrender. That judgment surely puts a special priority on finding these adversaries. This is a priority even higher than our commitment to rooting out terrorism in general. We are not at war with the domestic white racists who spawned the bombing of the federal building in Oklahoma City, as much as we may want to put a stop to their activities. Nor are we at war with, for example, the Greek group known as September 21, even though this group has been responsible for a number of violent attacks over many years that we undoubtedly would like to prevent. The equal protection clause does not require us to make war against all of our adversaries; we must and we can choose priorities, and those choices should echo in any equal protection analysis of the steps we take to protect ourselves against what we face.

\section{Profiling as a Response to Terrorist Emergencies}

To discuss the other part of the formula, whether the discriminatory action is "necessary" to the compelling governmental interest, requires us to be more concrete. What sort of actions are we discussing? Let us consider this possible scenario:

* A building is blown up in lower Manhattan. Eye-witnesses report that a group of men said to be of Middle Eastern appearance were seen running from the vicinity of the building shortly before the explosions. Meanwhile, a Middle Eastern group known for its extremist Islamist

30. Congress passed, and on September 18, 2001, the President signed, an "Authorization for Use of Military Force," S.J. Res. 23, 107th Cong. (2001) (enacted), which authorized the President "to use all necessary and appropriate force against those nations, organizations, or persons he determines planned, authorized, committed, or aided the terrorist attacks that occurred on September 11, 2001, or harbored such organizations or persons, in order to prevent any future acts of international terrorism against the United States by such nations, organizations or persons." Assuming this is a valid initiation, though not a declaration, of war, it is not, by its terms, a war against all terrorists everywhere, but only against those responsible for the September 11 attacks. (For the President's signing statement, see Press Release, President Signs Authorization for Use of Force Bill (Sept. 18, 2001), at http://www.whitehouse.gov/news/releases/ 2001/09/20010918-10.html (last visited Sept. 7, 2002)). 
politics phones local media to claim responsibility for the bombing. The caller says "no building is safe any more," and tells the media to tell everyone who values their safety "to stay home this week." The calls, and other information, convince the authorities that this is a credible threat. The government throws up barricades outside every large building in New York, begins requiring identification from every entrant and also starts searching randomly selected entrants. In addition, the government begins searching building entrants who fit a "terrorist profile" it has developed in light of this and other events. In this profile, being "Middle Eastern and Muslim" counts as a factor (not automatically sufficient by itself, nor necessary in every instance, but an important factor) pointing towards a need for further inquiry.

Is the government's response "necessary" to the compelling goal of preventing further terrorist attacks? That depends on just what we mean by the word "necessary." ${ }^{11}$ It would be possible, after all, to shut almost every large building in New York. ${ }^{32}$ Everyone could be told to do just what the caller said - to stay home. In fact, as we remember, after the airplane hijackings on September 11, 2001, the entire civilian air transportation system was shut down. But it can't be the case that we are obliged to respond to terrorist threats by shutting down our society. In fact, we have another compelling governmental interest, the interest in maintaining our society and its institutions, and this interest would be ill-served by massive closures.

If, then, we are entitled to try to remain open for business even as we seek to prevent terrorist attacks, what steps can we take to prevent our buildings from being blown up? One answer is that we can take only steps that are nondiscriminatory. We could, for example, search everyone when they entered any of these buildings. (We could, at least, provided that doing so is not in itself a breach of civil liberties; I am assuming in this essay that the steps in question are permissible as long as they are nondiscriminatory, in order to explore whether there are any circumstances in which they would also be permissible even if they

31. It has been clear at least since McCulloch v. Maryland, 17 U.S. 316, 413-15 (1819), that this term is not self-defining, and that it does not automatically mean absolute, inescapable necessity. As noted earlier, see supra note 22, I do not believe that focusing on "close tailoring" instead of "necessity" would materially alter this analysis.

32. Not all, though; hospitals and other buildings where essential services are constantly provided could not be closed without risking loss of life. 
were discriminatory. ${ }^{33}$ ) In this sense, it is, again, not "necessary" to the prevention of terrorism to single anyone out. But doing so might literally be impossible - could we muster the police or troops to search every person entering every large New York building? It would certainly be impractical, since implementing this profusion of searches would in effect shut down much of our society. Thus it would, again, disserve our compelling governmental interest in avoiding just that sort of defeat at the hands of our enemies. Moreover, trying to do this would be futile; the caller and his group, if they are serious and resourceful, will find a target that isn't a large building - there are many possibilities - and take advantage of the absence of full-scale protection there.

We cannot employ maximum effort on every person, but we could employ maximum effort on people selected in nondiscriminatory ways. This is, in fact, what airlines now routinely announce they are doing. Everyone is scrutinized more than they would have been before $9 / 11$, but a few people on each flight are, it is said, randomly selected for additional scrutiny. Early in 2002, my daughter, who was 6 years old at the time and travelling with her mother, was selected this way. Her backpack was opened and searched, and she was subjected to a metal detector wand and patdown search of her body.

This is proof that it is possible to avoid discrimination in security measures, but it is not proof that it is wise to do so. It may be that we live in a world where someone is prepared to use his 6-year-old daughter in a terrorist plot; if we're not in that world yet, it may be that we would soon enter it if terrorist adults realized that 6-year-old girls were getting a free pass. Random searches, and universal searches, both make sense because we are far from sure what our adversaries will look like. But it isn't conceivable that 6-year-old girls pose the same threat to airline security - or, to go back to my example, to the security of New York buildings - as grown men do. So if 6-year-olds are actually as likely to be randomly searched as grown men are, then some substantial amount of law enforcement effort is being largely wasted, as far as preventing terrorist attacks is concerned. ${ }^{34}$

33. Cf. Whren v. United States, 517 U.S. 806, 813 (1996) (observing that "[s]ubjective intentions play no role in ordinary, probable-cause Fourth Amendment analysis," and that "the constitutional basis for objecting to intentionally discriminatory application of laws is the Equal Protection Clause, not the Fourth Amendment").

34. There are many reports of airport searches equally unlikely to result in catching potential terrorists. See, e.g., Edward Wong, Aipport Has a No-Nonsense Approach to Security, N.Y. Times, July 7, 2002, at 15 (reporting a passenger's statement that "security workers in Phoenix had run a wand over her 2-year-old son, Devin, and asked her to take off his shoes." Devin, Wong writes, "looked about as dangerous as a newborn kitten."); Simmons Addresses Muslims, The Bulletin's Frontrunner, June 24, 2002 (quot- 
If we cannot rely on a combination of screening everyone to the limited extent feasible while more intensively screening a few people selected on a random basis, then we need a non-random basis for choosing some of the people whom we will scrutinize more thoroughly. (Some use of random searching still seems wise, however, to try to dissuade, or catch, those who might seek to slip through the net

ing New London Day, June 24, 2002) (Congressman Robert Simmons said he flies back and forth between Connecticut and Washington, D.C., almost every week, often on a one-way ticket purchased just hours before. He gets searched, he said, probably more often than anyone else, except for other congressmen and senators"); Stuart Taylor, The Skies Won't Be Safe Until We Use Commonsense Profiling, THE NAT'L J., available at http:/ /www.theatlantic.com/politics/nj/taylor2002-03-19.htm (Mar. 19, 2002) ("randomly chosen grandmothers, members of Congress, former CIA directors, and decorated military officers" frisked at airports); Joe Sharkey, A Onetime Top Executive Says Airline Security Has Often Been Secondary to Not Ruffling Customers, N.Y. Times, Jan. 23, 2002, at 8 (search of former Vice President Quayle; strip-search of Congressman John Dingell). Anna Quindlen has criticized random searches of women, arguing that " $[\mathrm{g}]$ ender is clearly key, despite the sudden spate of three suicide bombings in Israel by women. . . . Who knows who could be sliding by while security personnel are checking my lipstick for Plasticine?" Anna Quindlen, Armed With Only a Neutral Lipstick, Newsweek, Mar. 18, 2002, at 72. Cf. Gross \& Livingston, supra note 3, at 1425 ("After September 11, nobody could seriously complain about the FBI paying more attention to reports of suspicious behavior by Saudi men than to similar reports about Hungarian women."); Stuntz, supra note 6, at 2179 (similar comparison of airport security attention to "travelers with Danish visas and travelers with Yemeni visas").

See also Rob Asghar, A Show of Grace for Safety's Sake; Airline Passengers Need to Tolerate a Benign Profiling, L.A. Times, July 6, 2002, Part 2, at 23 (Asghar, "a youngish South Asian male traveling alone," criticizing the fact that he was not searched during air travel, urges: "stop strip-searching the little old white lady and take another gander at me the next time I come walking through LAX"). While Asghar's view is certainly not shared by all Muslims or Arabs in the United States, shortly after the September 11 attacks $61 \%$ of Arab-Americans polled in the Detroit area (home to "the nation's most visible community of Arab immigrants and descendants, estimated at 200,000 350,000 ") said that "profiling, or extra scrutiny of people with Middle Eastern features or accents" was "justified." Dennis Niemiec \& Shawn Windsor, Arab Americans Expect Scrutiny, Feel Sting of Bias, Detroit Free Press, Oct. 1, 2001, available at http://www. freep.comm/news/nw/terror2001/poll1_20011001.htm (last visited Aug. 9, 2002). Another poll of Arab-Americans in May 2002 found that $48 \%$ of those polled believed that it is "justified" for "law enforcement officials to engage in extra questioning and inspections of people with Middle Eastern accents or features," while $43 \%$ disagreed. Seven months earlier, the same polling agency had found slightly greater approval rates (54\% calling profiling justified, while $36 \%$ considered it unjustified). Zogby International, The Views of Arab Americans Toward Their Ethnicity Since September 11 (May 31, 2002) (on file with the author) [hereinafter cited as Zogby International, The Views of Arab Americans]. The Arab-American community is no more monolithic than any other, however, and it is notable that $61.0 \%$ of Muslim Arab-Americans polled in May 2002 felt that profiling was unjustified. 
by falling outside the categories subject to deliberate search. ${ }^{35}$ ) Essentially there are only three alternatives. First, we can select people for additional screening based solely on race, religion and similar factors. Second, we can select based solely on individual behavioral factors, such as nervousness or (at an airport) lack of a round-trip ticket, while altogether excluding race, religion and similar factors. Or, third, we can consider all of these factors together.

The first alternative, of screening solely on the basis of race and comparable factors, is both discriminatory and foolish. Arabs and Muslims - to name the two most obvious targets for such reactions today - are part of the American mainstream. Many are citizens. The vast majority, citizens or noncitizens, are altogether innocent of any connection with terrorism. Meanwhile, some people who are not Arabs John Walker Lindh and Jose Padilla come immediately to mind as proven, or alleged, instances - have apparently joined our enemies in $\mathrm{Al}$ Qaeda, ${ }^{36}$ and what apparently is an Al Qaeda instruction manual tells members to adopt a Western lifestyle that might make them unidentifiable as Muslims. ${ }^{37}$ And this is to say nothing of the second worst terrorist in United States history, Timothy McVeigh - a white man with no links to Islam. ${ }^{38}$ To screen solely on the basis of discrimi-

35. A profile is not useless simply because it may be evaded, provided that evasion is not easy (for example, because recruiting terrorists who do not fit the profile is also not easy) and provided that the profile does not beguile us into ignoring the possibility of its evasion.

36. Lindh, who recently pled guilty to two of the charges against him, is a white American, "raised in affluent Marin County, Calif.," who "discovered Islam as a teenager and immersed himself in it," and then "joined forces with Taliban troops" in Afghanistan. A Surprise Ending to Lindh's Strange Story, Austin Am. Statesman, July 16, 2002, at A10. Jose Padilla, also known as Abdullah al-Muhajir, has been accused of plotting to use a nuclear "dirty bomb" against the United States, and is now being held as an "enemy combatant." He has been reported to be a "former Chicago gang member." See Benjamin Weiser, U.S. Defends Decision to Move Suspect in 'Dirty Bomb' Case, N.Y. Times, July 19, 2002, at A15.

37. The manual, according to the Department of Justice, "was located by the Manchester (England) Metropolitan Police during a search of an al Qaeda member's home. The manual was found in a computer file described as 'the military series' related to the 'Declaration of Jihad,' The manual was translated into English and was introduced ... at the embassy bombing trial in New York." The Al Qaeda Manual, available at http://www.usdoj.gov/ag/trainingmanual.htm [hereinafter cited as "Al Qaeda Manual"]. Among the instructions in the "Fourth Lesson" on "Apartments - Hiding Places" are cautions against "[a]voiding seclusion and isolation from the population" and in favor of "rent[ing] these apartments using false names, appropriate cover, and non-Moslem appearance."

38. The FBI also has suspected that the person responsible for the anthrax letters is "a skilled scientist, acting alone, who works or worked in one of a handful of labs involved in the U.S. biowarfare program." Eric Rich, Anthrax Mystery Turns Scholars Into 
natory factors would offensively intrude on the lives of vast numbers of innocent people, while certainly missing some very guilty ones.

The second alternative is to scrutinize people based solely on individual behavioral factors. The factors to be taken into account would depend on the context, but presumably they would be of two types objective and subjective. At an airport, objective factors might include the lack of a round-trip ticket, or the lack of luggage; subjective considerations might include nervousness or failure to respond readily to initial, universally applied security procedures. If we can proceed this way, achieving protection without discrimination, we should. But there are important reasons to be skeptical of the promise of this approach.

First, while this system would be nondiscriminatory if applied as designed, in practice it surely would not be unfailingly applied this way. On the contrary, once subjective considerations are allowed to play a role in security decisions - and it is hard to argue that such potentially relevant factors as "nervousness" should be ignored - it seems inevitable that generalizations and stereotypes that are thought to bear on security will sometimes affect the decisions actually made. ${ }^{39}$ Men who appear to be Muslims, and whose identification papers reflect that they are from the Middle East, will be more likely to be seen as "nervous" or "uncooperative" than, say, white women from Illinois. ${ }^{40}$

Sleuths, Hartford Courant, Feb. 6, 2002, at A1. Recently a great deal of very public law enforcement attention has focused on a single scientist, a white American man, who apparently fits the profile of a potential anthrax terrorist. It is by no means clear that this individual is guilty of anything, however, and the New York Times has commented that the FBI, "and the nation, should be careful about fitting someone to the profile and assuming he is guilty before he is charged, tried and convicted." See Editorial, The Anthrax Investigation, N.Y. Times, Aug. 14, 2002, at A22. Needless to say, these events are a reminder that even very narrowly focused profiles can be inaccurate. The widespread assumption by profilers of serial killers that the snipers who terrorized the area around Washington, D.C. in the fall of 2002 were white appears to be another proof of this proposition. See Steven A. Holmes, An Assumption Undone: Many Voice Surprise Arrested Men Are Black, N.Y. Times, Oct. 25, 2002, at A26.

39. See David A. Harris, Profiles in Injustice: Why Racial Profiling Cannot Work 26-28 (2002). Such mental shorthand is particularly unavoidable when people must make many, very quick decisions - as, for example, at our borders. The chief of Customs in Laredo, Texas recently commented that "The guy on the line has to make a determination within seconds whether to intensely examine someone." Tim Weiner, Traces of Terror: Immigration Security; Border Customs Agents Are Pushed to the Limit, N.Y. Times, July 25, 2002, at A14 (quoting Rudy Santos).

40. See Robert E. Pierre, Fear and Anxiety Permeate Arab Enclave Near Detroit; Muslim Americans Feel They Are Targets in War on Terror, WASH. POsT, Aug. 4, 2002, at A3 (“In Seattle, Arab Americans complain of being regularly reported to the police for taking pictures of Boeing Field from a tour boat, or for entering a 7-Eleven and then deciding not to buy something, said Rita Zawaideh, founder of the Arab American Community Coalition there"); Lydia Polgreen, Actress's Detainment Upsets Indians in U.S. and Abroad, 
Even purportedly objective factors can become so diverse and all-encompassing that there is always a factor available in every case, as in border-control contexts where both "making eye-contact" and "not making eye-contact" have become factors on which stops have been based. 41

It is important to recognize, therefore, that one aspect of the answer to the question of whether racial profiling should be a response to terrorism is simply that it will be - whether this is authorized or not. To say that there will be some discrimination even under nondiscriminatory rules does not, of course, mean that the rules should authorize discrimination. If discrimination is not an ineradicable aspect of

N.Y. Times, July 19, 2002, at B2; Lydia Polgreen, Bollywood Farce: Indian Actress and Family are Detained, N.Y. Times, July 18, 2002, at B1; Bart Jones, Suspicion Casts a Wide Net; Immigrants' Photos Lead to Questions, NewsDay, June 27, 2002, at A28 (Long Island resident of Indian descent contacted at his home by police after he and Indian immigrant friends take photographs of themselves at scenic point). See also "Andy Newman, Ideas and Trends: Look Out; Citizen Snoops Wanted (Call Toll-Free), N.Y. Times, July 21, 2002, § 4, at 1 (quoting Federal Express driver who "routinely passed on information about what he saw in Arab-American customers' apartments": "'Whenever I would go to a place where there was a lot of them,' he said, "'I would tell the landlord, hey, you got nine people living up there or whatever, and they would call the F.B.I. and get them checked out.,").

These events reflect over-reaction and perhaps prejudice, but another recent event points to the difficulty of discounting profile factors altogether. Reportedly, on June 11, 2002, two men "described as Middle Eastern" "offered to pay cash on the spot for an ambulance in the lot" of a company called Movie Time Cars. To own a vehicle seemingly entitled to special access could be of value to a terrorist, and reportedly has been in Israel. The company owner reported this event to the police, along with the men's license plate number. Surely the ethnic appearance of the would-be purchasers was not wholly irrelevant to the degree of alarm the owner could reasonably have felt, though the local police decision to put out a "nationwide All Points Bulletin for the men" as a result seems more panicky than prudent. Deborah Feyerick, Terrorism Task Force Eyes Attempt to Buy Ambulance (June 20, 2002), at http://www.cnn.com/2002/US/06/20/ ambulance.buyers/. See also Timothy Egan, The Reaction in Portland: A Mixed Picture of Oregon Suspects, N.Y. TIMEs, Oct. 5, 2002, at A11 (members of alleged terrorist cell arrested after a "yearlong surveillance," which began "after a sheriff in rural Skamania County, Washington ... saw men in turbans shooting rifles at a gravel pit," and contacted the FBI).

41. See HARris, supra note 39, at 29-30. The Supreme Court has recently emphasized that the same behavior may justify reasonable suspicion in one context though it would not in another, and observed that " $[\mathrm{t}] \mathrm{o}$ the extent that a totality of the circumstances approach may render appellate review less circumscribed by precedent than otherwise, it is the nature of the totality rule." United States v. Arvizu, 122 S. Ct. 744, 751 (2002). As William Stuntz has emphasized, Justice O'Connor's comments during the November, 2001 oral argument of this case strongly suggest that she, and perhaps the Court as a whole, considered this issue in light of the danger of terrorism. Stuntz, supra note 6, at 2157-58. 
human behavior, then a determined effort to suppress it, reflected in rules that give it no place, should be more successful than an approach that indulges or welcomes it. David Harris has persuasively outlined a range of management steps that seem well calculated to find and at least reduce this kind of law enforcement. ${ }^{42}$ There have in fact been some apparent successes in reducing profiling in the months since September 11.43 But the effort at suppression will not be perfectly successful.

42. HARRIS, supra note 39 , at $145-207$. William Stuntz is more skeptical, arguing that "racial and ethnic profiling is a fact of life that the legal system probably cannot change." Stuntz, supra note 6, at 2179. My own view is that the kind of stereotypical, systematic profiling of large numbers of people seen, for example, on America's highways, can be effectively prohibited. What cannot be prohibited is the impact of race as a factor, sometimes a huge factor, shaping intuitions; this follows, as R. Richard Banks argues, from the tremendous salience of race as an organizing factor in our entire society. Banks, supra note 27, at 1109-12, $1117 \mathrm{n} .173$.

43. An organization called "The Sikh Coalition" maintains a website compilation of complaints of discrimination against Sikhs since September 11. Because Sikh men wear turbans as a matter of religious duty, and because they are Asians, they became the victims of many unpleasant and intrusive incidents in airports after September 11, despite specific guidance from the U.S. Department of Transportation meant to prevent such treatment. See U.S. Dept. of Transportation, Fact Sheet: Answers to Frequently Asked Questions Concerning the Air Travel of People Who Are or May Appear to Be of Arab, Middle Eastern or South Asian Descent and/or Muslim or Sikh, at http://www.caasf.org/0901/ al_usdotFAQ.html (last visited Sept. 11, 2002) [hereinafter cited as "DOT Fact Sheet"]. A count by my research assistant of the airport incident reports, however, strongly suggests that this problem has now been addressed; after 11 complaints about events in October 2001, and 12 about November ones, there have been only 13 such complaints through July 2002, and only 5 after February 2002. Between July and mid-November 2002, there were no posted airport profiling complaints. The reports are available at http://www.sikhcoalition.org/List Reports.asp (last visited Nov. 13, 2002). See also Laura J. Brown, Airport Profiling of People of Arab and Muslim Descent Greatly Decreased (Dec. 21, 2001), available at http://usinfo.state.gov/usa/race/profile/a122101.htm (last visited July 24, 2002).

Somewhat similarly, the American-Arab Anti-Discrimination Committee has "confirmed over 700 violent incidents" against Arab-Americans since September 11, but Hussein Ibish, the AADC's Communications Director, commented in May that "that number has been steadily declining." CNN Late Edition with Wolf Blitzer, May 5, 2002, available at http://www.adc.org (last visited Aug. 5, 2002). Ibish also observed that "[ $\mathrm{t}]$ he rate of hate crimes has dropped back to 'normal' levels, if I can use that term." Jim Edwards, Statistics Don't Bear Out Feared Increase in Bias Cases Against Muslims and Arabs, The Legal InTElligencer, June 17, 2002 available in Westlaw at 6/17/2002 Legal Intelligencer 4 . Though this decline hardly means Arab-Americans face no discrimination in their lives, it is not implausible to attribute the reduction in violence in part to the efforts by the government to avoid attributing guilt to all Muslims or Arabs (even as it vigorously pursues potential terrorists among immigrants from countries with $\mathrm{Al}$ Qaeda links, countries that also tend to be Muslim and/or Arab, see supra note 17 ). So the Republican Congressman Darrell Issa, himself of Lebanese descent, felt, when he 
Just how unsuccessful depends on several factors. These include irrational prejudices against which we should always struggle, such as sheer bias against Muslims or Arabs. They also include reactions which may be somewhat irrational too, but are easier to excuse - notably, terror, which we can expect to feel precisely in proportion to the extent to which we are in fact terrorized in the future. Finally, however, the tendency to profile will reflect whatever reality there is to the profile; if, indeed, profiling appears to be effective in this context, then it will always be a struggle to get police and public to put out of their frightened minds a reality they are aware of. We might still try to prevent profiling even if it did make sense, on the ground that it is also pernicious and harmful - and I will turn to a direct assessment of the merits and demerits of profiling below - but it would be hard.

Second, this system will have costs. Some of those will be measured in evasion and dishonesty, as law enforcement personnel find pretexts for reasoning that cannot be acknowledged. Other costs may be measured in public safety, if officers disregard correct (and entirely legitimate) intuitions out of self-censorship. It is not fanciful to expect that one human response to a prohibition on profiling will be that some officers will overreact and seek to prohibit even intimations of profiling, at the risk of practical good sense. ${ }^{44}$ Finally, even if the system works exactly as designed it may have a real cost: if profiling could improve the accuracy of our screening systems (an issue I take up in a moment), then - all other things being equal - systems that succeed in avoiding all profiling will lose that incremental accuracy. There is certainly reason to believe that the non-racial factors overtly considered in the current screening system are far from perfect guides; as Stuart Taylor has observed, the behaviors apparently now treated as worth attention - "paying cash, holding a one-way ticket, acting furtive, arriving recently from Pakistan, and the like - are not all that hard to avoid." 45

characterized this improvement as "a sign of the leadership President Bush applied to saying this is not about Islam, this is not about residents of the United States, this [sic] about a small group of zealots that committed an atrocity against America." CNN Late Edition with Wolf Blitzer, supra. I will return to the question of the overall climate facing Arab- and Muslim-Americans below. See infra text accompanying notes 107-16.

44. Cf., Timothy Egan, Killing of White Deputy Quiets Protests Over Police Shootings of 2 Blacks, N.Y. TIMEs, July 13, 2002, at A7(after killing of a police officer, other officers ask whether he "had feared using his gun out of concern that he might be criticized later").

45. Taylor, supra note 34. Taylor adds that, "offensive or no, the only profiles likely to be effective against a well-trained terrorist are those triggered by traits that he cannot change or easily conceal." It is important, however, not to overestimate the capacities, or invisibility, of those who now threaten us. As Taylor notes, id., of the 19 hijackers on September 11, 9 were actually subjected to special scrutiny based on the 
We should also recognize that even the partial success in suppressing racial profiling that nondiscriminatory rules might foster will be the result not just of the rules but of a serious commitment to enforcing them. It is possible to imagine a system in which the stated rules abjure discrimination, but also give security personnel so much discretion, and review the exercise of that discretion so little, or so indulgently, that in effect the system is a license to discriminate covertly. Racial profiling on American highways may have been part of a system operating like this. ${ }^{46}$ It is also possible that airport screening right now operates this way, though I do not believe this is the federal government's intention. Transportation Secretary Norman Mineta, himself a Japanese-American victim of the World War II internments, has spoken emphatically against profiling. ${ }^{47} \mathrm{~A}$ Department of Transportation "Fact Sheet" reiterates the Department's commitment "to ensuring that all persons are provided equal protection of the laws and that no person is subject to unlawful discrimination when traveling in the Nation." 48 But the same document repeatedly declares that no one should be specially screened or searched at an airport "solely" on the basis of ethnicity or religion, and that reiterated word could be read to imply the proposition that ethnicity or religion can be part of the basis

evidently non-racial profiling factors in place that day. The level of scrutiny was quite restricted, however, id., and as we learned to our sorrow, FAA rules at the time did not actually prohibit passengers from bringing box cutters on to planes. Stuart Taylor Jr., D.C. Dispatch: Politically Incorrect Profiling: A Matter of Life or Death (Nov. 6, 2001), THE NAT'L J., available at http://www.theatlantic.com/politics/nj/taylor2001-11-06.htm (last visited July 24, 2002). No doubt more vigorous scrutiny of these 9 men could have made a difference on September 11. But if we can find ways to target more than 9 out of 19 potential terrorists, and if the social costs of those methods are not too great, we have reason to employ them. Here, as elsewhere, however, we must weigh costs and benefits; the more effective we can make our screening in the future without using racial profiling or similar steps, the less justification for turning to these methods. Cf. Editorial, Airport Security, a Year Later, N.Y. Times, Sept. 20, 2002, at A26 (noting that " $[\mathrm{t}]$ he Transportation Security Administration is working on a second-generation passenger-profiling computer program designed to link numerous databases to help determine whether passengers need particularly close scrutiny").

46. David Harris emphasizes the high discretion the law gives police in situations such as "stop and frisks" and highway stops. HARris, supra note 39, at 30-47.

47. See CBS News Transcripts, 60 Minutes, That Dirty Little Word 'Profiling': Pros and Cons of Profiling Arab-American Men at Airports After the September 11th Attacks, Dec. 2, 2001 available in LEXIS NEws AND BUs. [hereinafter cited as "60 Minutes Transcript"].

48. DOT Fact Sheet, supra note 43, at 1. See also Office Of Civil Rights, Federal Aviation Administration, FAA Fact Sheet: Non-Discrimination on the Basis of Race, Color, National Origin, Sex or Creed, at 1, available at http://www.faa.gov/acr/AT-Titl6.doc (last visited Sept. 11, 2002) ("None of the new security measures decrease the responsibility of airports and airlines to enforce [federal laws and regulations] regarding discrimination."). 
for law enforcement action. ${ }^{49}$ Secretary Mineta believes that in general "a 70-year-old white woman from Vero Beach, Florida" should "receive the same level of scrutiny as . . . a Muslim young man from Jersey City." ${ }^{0}$ Muslims, however, report that they are receiving much more attention than that ${ }^{51}$ - even if a number of non-Muslims are being

49. The same Fact Sheet instructs airport security personnel to ask themselves whether they would be taking a given step but for the fact that the passenger in question is a member of a potentially profiled group. DOT Fact Sheet, supra note 43 , at 3 . Rigorously applied, this "but for" test would preclude using factors such as race or religion to tip the balance in any case. $C f$. Mt. Healthy City School Dist. v. Doyle, 429 U.S. 274, 285-87 (1977) ("but for" test in First Amendment setting). But it must often be tempting for anxious security officers to reason that they have only considered these factors in an ancillary way, when an outside observer would conclude that these elements were critical to the officers' decisionmaking.

50. 60 Minutes Transcript, supra note 47 , at 1 .

51. See Fareed Zakaria, Freedom vs. Security, Newsweek, July 8, 2002, at 26 ("As a swarthy young man with an exotic name, trust me, we're being checked. I don't know what the system is and how much discretion is allowed the security guards at the gates, but I've taken more than 50 flights all over the country since September 11, and I've been searched about 60 percent of the time. Either they are checking me out or I'm the unluckiest man alive."); Kareem Shora, Guilty of Flying While Brown, 17 AIR \& SPACE L. 4, 4 (2002), available at www.adc.org (last visited Aug. 6, 2002) ("Unfortunately, it is now a common expectation in our country for, primarily, men of Middle-Eastern or South Asian origins, to encounter a nervous flight attendant or airline pilot who requests that the man follow them out of the plane after boarding. Once the man is in the jet-way or gate area, he is informed that he is not welcome on the flight because 'the crew does not feel comfortable with [him] on board,' or 'a passenger does not feel safe with [him] on board.'"); Phil Hirschkorn \& Michael Okwu, Airlines Face Post 9/11 Racial Profiling, Discrimination Suits (June 4, 2002), available at http://www.cnn.com (suits by "[f] ive passengers who were removed from or prevented from boarding flights" in 2001); The Secret Service Officer: Pilot Says Officer's Actions Led to Refusal of Passage, N.Y. TIMEs, Jan. 4, 2002, at A15 (Arab-American Secret Service officer "refused passage" on plane by pilot, apparently in part because he was carrying a "Middle Eastern history book"); Bina Ahmad, People of Color Bearing the Brunt of Post-Sept. 11 Climate, SAN Diego UNION-TRIBUNE, June 23, 2002, at G6 (describing the author's experience of being racially profiled at an airport on October 10, 2001). See also Zogby International, The Views of Arab-Americans, supra note 34 (78\% of Arab-Americans polled in May 2002 think that there has been more profiling of Arab-Americans since the September 11 attacks).

Interestingly, however, a recent poll of Muslims in America found that, of the 26.6 $\%$ of respondents who said they had experienced anti-Muslim "discrimination, harassment, verbal abuse, or physical attack since Sept. 11," only $3.6 \%$ identified the location of the most recent such incident as an airport. The street, work, school and "other" were the most common locations. Hamilton College Muslim America Poll, May 30, 2002, at 10-11 (hereinafter "Muslim America Poll"). It is difficult to tell whether this poll reflects that airport profiling is not as frequent as it probably was in October 2001, or that profiling is still frequent but is accepted as reasonable, or simply that most Muslims in America fly relatively infrequently. An indication that the number of these incidents is not trivial, and that the incidents are not welcomed, comes from data on the 
fruitlessly searched as well ${ }^{52}$ - and the guideline's ambiguity certainly leaves room for security staff to rationalize discriminatory action.

There are times when for institutional reasons it may actually be right for courts to avoid adjudicating legally valid claims, ${ }^{53}$ but the idea that we would deliberately permit racial profiling while pretending that we didn't is repellent. Not to admit a legal issue exists is, in itself, a departure from the rule of law - and a departure visible in the United States legal system's response to the internment of Japanese-Americans during World War II. ${ }^{54}$ The experience with highway profiling in the drug war, moreover, suggests that the truth will out - and that meanwhile the victims of the open secret will become increasingly outraged. ${ }^{55}$ In this essay, therefore, I want to contrast a seriously applied, but inevitably not entirely effective, prohibition on such profiling with an alternative, to which I now turn.

That alternative is, as already indicated, to allow considerations of race, religion, national origin and gender to be taken into account along with individual behavioral characteristics behavioral characteristics. If these discriminatory factors do have actual relevance to the like-

website of the Council of American-Islamic Relations (CAIR), which compiled reports of "Anti-Muslim incidents" and, as of February 8, 2002, reported 1717, of which 191, or $11.1 \%$, involved "airport profiling. "See Leti Volpp, The Citizen and the Terrorist, 49 UCLA L. Rev. 1575, 1575 n.1 (2002) (citing data available on February 8, 2002 on the Council's website, at http://www.cair-net.org) (these data remained the same when the site was last visited on Aug. 9, 2002)). For polling data suggesting that most Mulsim Arab-Americans, but not most Arab-Americans as a whole, oppose profiling, see supra note 34 .

52. See supra note 34 .

53. Many denials of certiorari by the Supreme Court may reflect such reasons. Justice Jackson, in Korematsu, commented that "I would not lead people to rely on this Court for a review that seems to me wholly delusive. The military reasonableness of these orders can only be determined by military superiors. ... I do not suggest that the courts should have attempted to interfere with the Army in carrying out its task" even though, when the government sought the courts' aid in enforcing the Japanese relocation orders, it was the courts' duty, he felt, to hold them unconstitutional. Korematsu v. United States, 323 U.S. 214, 248 (1944) (Jackson J., dissenting).

54. A.W. Brian Simpson has commented that "it seems to me important, especially for lawyers, not to be overly impressed with legal technicalities and dogma that produce a situation in which over 60,000 citizens are held in detention for up to three years, and indeed released at the end of it, before the legal system has gotten around to saying whether their detention violated the Constitution or not." A.W. Brian Simpson, Detention Without Trial in the Second World War: Comparing the British and American Experiences, 16 Fla. St. U.L. Rev. 225, 251 (1988).

55. See, e.g., Harris, supra note 39, at 108-10 (reporting a statement by Saul Green, an African-American United States Attorney in Michigan, describing the advice Green felt he had to give his teenage son about the racial profiling the son could expect while driving). 
lihood that a particular person is a terrorist, then at first blush it would seem that taking these factors into account, along with the others, would enable security officers to take into account the widest possible range of relevant information - and that, in principle, is good.

Obviously, however, there is no basis for taking these discriminatory factors into account if they do not have actual relevance to the likelihood that a particular person is a terrorist. Actual relevance may be far from sufficient to justify such a policy, but it is certainly necessary to justify it. Moreover, as I've already mentioned, it is clear that our adversaries are a somewhat diverse group. We now have reason to believe that they include U.S. citizens fighting alongside Al Qaeda or the Taliban, and that among these citizens are individuals of Arab, Hispanic, and "Anglo" background. ${ }^{56}$ A French citizen of North African descent and a Briton of partly Jamaican descent are also among those alleged to have tried to attack us. ${ }^{57} \mathrm{Al}$ Qaeda as an organization has apparently reached into Muslim communities around the world, and worked with Muslim radicals in Africa, Asia, Europe and the United

56. Yaser Esam Hamdi, now being held as an enemy combatant after allegedly being captured in Afghanistan while armed, was born in Louisiana to Saudi parents and apparently is still a U.S. citizen. See Tom Jackman \& Dan Eggen, Combatants Lack Rights, U.S. Argues; Brief Defends Detainees' Trealment, WASH. Post, June 20, 2002, at A1; Prosecutors Detail 'Enemy Combatant' Case, N.Y. Times, July 26, 2002 available at http://www.ny times.com (last visited July 26, 2002). For background on John Walker Lindh and Jose Padilla (Abdullah al-Muhajir), see supra note 36. See also Ira Silverman, An American Terrorist, THE NEw Yorker, Aug. 5, 2002, at 26 (describing political assassination committed in 1980 by "Dawud Salahuddin, a twenty-nine-year-old African-American convert to Islam who was born David Theodore Belfield"; Salahuddin has lived in Iran, except for short stays elsewhere, since 1980). Another African-American Muslim was arrested in July 2002 "as a material witness to terrorist activity."American Muslim Held in Terrorism Inquiry, Associated Press, July 24, 2002, available at http://www.nytimes.com/2002/ 07/24/national/24SEAT.html (last visited July 24, 2002); Candace Heckman, James Ujaama Speaks Out Against Scrutiny, Seattle Post-Intelligencer, July 20, 2002, at B1. See also Timothy Egan, The Reaction in Portland: A Mixed Picture of Oregon Suspects, N.Y. Times, Oct. 5, 2002, at A11 (arrests of three other African-American Muslims for alleged conspiracy "to aid Al Qaeda and the Taliban").

57. Zaccarias Moussaoui, a French citizen alleged to be the "20th hijacker," is the son of a Moroccan woman who immigrated to France. See Philip Shenon, Judge Clears Defendant to Meet French Diplomats, N.Y. Times, July 17, 2002, at A16; Richard Willing, 'Westernized Kid' Grous into 9/11 Suspect, USA TODAY, June 25, 2002, at 1A. Richard Reid, who recently pled guilty to having attempted to blow up an airplane with a bomb in his shoes, is "a British convert to Islam," reported to be "[h]alfwhite [sic], half West Indian." Jason Lewis et al., Moment the Shoe Bomber was Seized, The Daily Mail and Mail on Sunday, Dec. 30, 2001, at 4; Fox Butterfield, The Shoe Bomb Case: Qaeda Man Pleads Guilty to Flying With Shoe Bomb, N.Y. Times, Oct. 5, 2002, at A11. 
States. ${ }^{58}$ With the loss of its base in Afghanistan, Al Qaeda, and the Muslim terrorist movement which Al Qaeda did so much to foster, have if anything become more diverse. ${ }^{59}$

Does this mean that racial profiling simply makes no sense? The answer, probably, is no. For we also know that Al Qaeda is-or was, if it no longer formally exists-a Muslim organization, drawing a great many of its members and adherents from Middle Eastern states, and apparently open only to men. ${ }^{60}$. If potential terrorists are now a more diverse group, it is possible that the traits that have marked $\mathrm{Al}$ Qaeda,

58. One study of Al Qaeda emphasizes that "Al-Qaeda draws the support of both Arab and non-Arab Muslims. With time, Al-Qaeda's vast active and potential support based will grow and mature. ... Al-Qaeda physically and/or ideologically penetrates international and domestic Muslim NGOs throughout the world. Thus the Al-Qaeda infrastructure is inseparably enmeshed with the religious, social and economic fabric of Muslim communities worldwide." Phil Hirschkorn, Rohan Gunaratna, Ed Blanche \& Stefan Leader, Blowback, 13 Jane's InTElligence Review 42, 45 (Aug. 2001). A recent article on Al-Qaeda forces in Pakistan mentions "non-Arab Uzbeks, Chechens and Sudanese." Tim McGirk, Al-Qaeda's New Hideouts, Time, July 29, 2002, at 37-38. The prisoners now being held at Guantánamo evidently include Uighur Muslims from China. Erik Eckholm, Guantánamo Bay: Beijing Says Chinese Muslims Are Among Detainees in Cuba, N.Y. Times, Oct. 16, 2002, at A15. Another report states that "[w]ith law enforcement focused on the threat from Middle Easterners, intelligence officials believe that 'the next face of this is not going to be an Arab face, but possibly Indonesian, Filipino, a Malaysian face, or even African,' one senior official said. 'They understand the security profile we are operating on.'" Eric Pianin \& Bob Woodward, Terror Concerns of U.S. Extend to Asia; Arrests in Singapore and Malaysia Cited, WAsH. Post, Jan. 18, 2002, at A18. In fact, the F.B.I. recently "issued a warning . . . that Al Qaeda may be planning to attack passenger trains, 'possibly using operatives who have a Western appearance." Joel Brinkley, Domestic Security: F.B.I. Issues a Terror Warning, Citing Possible Threat to Trains, N.Y. Times, Oct. 25, 2002, at A15.

59. According to one commentator, "the organization has dispersed its adherents to groups and cells capable of operating independently, with the result that the global movement has gone local." Douglas Frantz, Defining Al Qaeda: "They're Coming After Us." But Who Are They Now? , N.Y. TIMEs, Oct. 20, 2002, at 12 (Week in Review). "Within the Federal Bureau of Investigation, some senior officials no longer use the name $\mathrm{Al}$ Qaeda. Instead, in recognition of the threat's broader dimensions, they refer privately to a radical international movement pursuing the United States and its allies." Douglas Frantz, Terrorism Watch: Al Qaeda Evolves Into Looser Network, Experts Say, N.Y. Times, Oct. 15, 2002, at A12. Al Qaeda's training camps, which trained up to 10,000 people, "were also vital centers where men from widely different backgrounds who had once had very different causes learned to trust and work with one another." Michael Elliott, Reeling Them In: Al-Qaeda's Elusive Terrorists Have to Be Captured One by One. The Inside Story of How a Big Fish Got Snared, Time, Sept. 23, 2002, at 28, 32.

60. According to Hirschkorn, et al., supra note 58 , at 43 , "[t] here are no female members." The Al-Qaeda manual states that "The member of the Organization must be Moslem." Al Qaeda Manual, supra note 37 ("Necessary Qualifications fro [sic] the Organization's Members," \# 1). While Hirschkorn, et al. emphasize how widely Al Qaeda has spread, they also observe that " $[\mathrm{m}]$ ost of Al-Qaeda's membership is drawn from ... 
and that marked the September 11 hijackers, are now irrelevant to identifying potential terrorists, but that seems unlikely. Perhaps the range of people who should be profiled must be expanded, and certainly it is important not to rely solely on profiling factors for our protection. But people sharing all of $\mathrm{Al}$ Qaeda's background characteristics still seem more likely to be our adversaries than most people who share none of them - even though the great majority of people sharing all of these characteristics have no connection to terrorism whatsoever. ${ }^{61}$ So long as our adversaries tend to be members of definable groups, in principle we should be better able to find them if we take group membership into account, not as either a necessary or a sufficient factor, but as a relevant one. As Stuart Taylor observes, "offensive or no, the only profiles likely to be effective against a welltrained terrorist are those triggered by traits that he cannot change or easily conceal." 62

How much better will our anti-terrorism work be? We do not know. Surely it will not be much better. But how much better does it need to be? For purposes of thinking about the question, let us assume a number. Suppose that there is only one chance in 1000 that taking information about race and religion into account, along with other factors, will help us to identify a terrorist. That means that in 999 cases out of every 1000 in which this factor is used, it will not help, and so people targeted because of the inclusion of this factor will, in 999 cases out of 1000 , be no more likely to be terrorists than others targeted solely on the basis of behavioral criteria. A great many people will, as a

two Egyptian groups," and that "Al-Qaeda's elite consists of experienced Egyptian, Algerian and Yemeni cadres." Hirschkorn, et al., supra at 51.

61. One useful indicator of where our adversaries come from is, surely, where they came from. All 19 September 11 terrorists were Middle Eastern, Muslim men. See Stuntz, supra note 6, at 2161. Another helpful guide may be the FBI's list of 24 "Most Wanted Terrorists". They include 4 people from Kenya ( 1 apparently also a citizen of the Comoros, and 1 apparently also a citizen of Egypt) and 1 born in the United States. All of the rest are from Middle Eastern or North African states: 7 from Egypt, 6 from Saudi Arabia, 3 from Lebanon, 1 from Libya, and 1 born in Kuwait (no citizenship stated). See http://www.fbi.gov/mostwant/terrorists/fugitives.htm (last visited July 23, 2002). Immigration screening policies also reflect the government's apparent judgments about where our adversaries come from. Thus the recent proposal to impose "fingerprinting, photographing, and registration requirements" on many foreign visitors, see supra note 17, mainly targets people from Middle Eastern states, though it also reportedly includes people from Pakistan, Malaysia and Indonesia. Raymond Bonner, Immigration: New Policiy Delays Visas For Specified Muslim Men, N.Y. Times, Sept. 10, 2002, at A12.

62. See Taylor, supra note 34. 
result, be subjected to inconvenient, perhaps embarrassing and demeaning, government inquiry for no good reason. ${ }^{63}$

On the other hand, once in a thousand times, considering race and religion will help us to identify someone who should be the subject of government interest. Actually, once in a thousand is not a bad rate at all in this context. We are, after all, engaged in an effort to prevent crimes, or acts of war, that could easily kill thousands of people in minutes, or instants. Moreover, universal screening techniques such as airport metal detectors may well have success rates of even less than 1 in 1000 , not because their technology is defective, but because almost no airport passengers are carrying dangerous materials onto planes - yet all these passengers are subjected to search. Presumably the random searches that are also conducted at airports have comparably high error rates, for the same reason. ${ }^{64}$ In short, if taking race or religion into account actually will improve our ability to identify terrorists in one case out of 1000 , that seemingly low figure should actually be counted as a strong reason to institute profiling that includes these factors. ${ }^{65}$ Even a rate of one in 10,000 - probably more plausi-

63. If the profiling program deters some would-be terrorists from attempting attacks, however, then the 1 in 1000 apprehension rate will clearly underestimate the program's utility.

64. David Harris repeats a police chief's comment that "a three in ten hit rate 'would get you into the Hall of Fame." See HARris, supra note 39, at 243 n.18.

65. The commentator Stuart Taylor has made, but exaggerated, a similar point, in his otherwise cogent article, Taylor, supra note 34 . He writes that: "The odds that any Middle Eastern passenger is a terrorist are, of course, tiny. But if you make the plausible assumptions that $\mathrm{Al}$ Qaeda terrorists are at least 100 times as likely to be from the Middle East as to be native-born Americans, and that fewer than 5 percent of all passengers on domestic flights are Middle Eastern men, it would follow that a randomly chosen Middle Eastern male passenger is roughly 2,000 times as likely to be an Al Qaeda terrorist as a randomly-chosen native-born American. It is crazy to ignore such odds." Taylor, supra note 34 . Taylor's " 2000 " figure is a statistical mistake; the fact that there are fewer Middle Easterners than native-born Americans on domestic flights does not increase the chance that any given Middle Easterner will be a terrorist, or decrease the chance that any given native-born American will be. So the true figure, in Taylor's example, is simply his original assumption - each Middle Easterner is 100 times more likely to be a member of $\mathrm{Al}$ Qaeda than each native-born American. (Even this is not exactly right; to say that Al Qaeda members are 100 times more likely to be Middle Easterners than to be native-born Americans is not to say that individual Middle Easterners are 100 times more likely to be $\mathrm{Al}$ Qaeda members than individual native-born Americans are. If there are more Middle Easterners in the world than there are native-born Americans, then each individual Middle Easterner would be proportionately less than 100 times more likely to be an Al Qaeda member than a native-born American would be.) Aside from the computational error, in any event, if the likelihood that an American is an $\mathrm{Al}$ Qaeda member is truly tiny, then the likelihood that a Middle Easterner will be is truly tiny too. Suppose the chance that an American is a member of Al Qaeda is 1 in 25 
ble empirically - would not be trivial, when the stakes are surpassingly high and the number of people being checked is very large, as it is, for example, in the nation's airports. ${ }^{66}$

million (so that there might well be 10 native-born American $\mathrm{Al}$ Qaeda members in the total population); that would mean that the likelihood for a Middle Easterner - 100 times greater - would be 1 in 250,000. How much suffering and social disruption would we be willing to endure, or impose, to increase our chance of catching that 1 in 250,000 by whatever degree - certainly less than perfection - profiling would enable us to? The numbers I use in text are much higher -1 in 1000 or $10,000-$ and if either of them is correct then it provides a more plausible basis for action, but we simply do not know what the true number is.

66. Again, it is impossible to be certain of the number of terrorists, or Muslim terrorists, in the nation. According to one report, however, "[t] he Federal Bureau of Investigation is trying to make an open book of the lives of hundreds of mostly young, mostly Muslim men in the United States in the belief that Al Qaeda-trained terrorists remain in this country, awaiting instructions to attack... The men are suspected of ties to Al Qaeda or other groups affiliated with Osama bin Laden's terrorist network. . . . [L]aw enforcement officials say they are convinced that at least several dozen people now under F.B.I. surveillance in the United States . . would take part in an attack if ordered, and that they represent a clear threat." Philip Shenon \&c David Johnston, Seeking Terrorist Plots, the F.B.I. Is Tracking Hundreds of Muslims, N.Y. Times, Oct. 6, 2002, at 1, 24. In contrast, Hussein Ibish, the American-Arab Anti-Discrimination Committee's communications director, "said there was an understanding among Arab-Americans that a handful of young men of Arab descent in the United States might pose a terrorist threat, and that it was in the best interests of the community here to find and stop them. 'I would be surprised if there are hundreds of them,' he said. 'But there could be $10,20,30$.' 'Id. at 24. There are approximately 690,000 Muslim Arab-Americans in the United States, of whom perhaps 250,000 might be adult men. (The Arab American Institute reports that there are 3,000,000 people of Arab descent in the United States, of whom $23 \%$ are Muslims. The Arab American Institute, Main Page, available at http:/ /www.aaiusa.org/index.htm (last visited Nov. 12, 2002). If 25 of these 250,000 are potential terrorists, then the ratio would be 1 in 10,000 . For an anti-terrorist profiling program to produce results in 1 case out of 10,000 , however, it is not necessary that 1 in every 10,000 people profiled be a terrorist. If the program uses ethnic and religious factors in conjunction with other indicators (nervousness, for example), then it might achieve this level of effectiveness even if the actual number of terrorists among the profiled population was distinctly less.

On the other hand, even if 1 of every 10,000 Arab-American Muslims is a terrorist, a profiling program might fall far short of a 1 in 10,000 success rate. If the profile was deliberately framed broadly, for example to encompass all Arab-Americans - on the theory that all Arab-Americans needed to be searched in order to be sure to search Muslim Arab-Americans - then the success rate could fall dramatically. The effect would be even greater if the actual application of the program was indiscriminate, sweeping non-targeted groups in to the profiled group simply out of misidentification. The haziness of such categories as "Middle Eastern" makes this a likely possibility. (I am grateful to my colleague Sadiq Reza for pointing out these prospects.) Worrisome as these potentials are, they do not change the basic points I am making: a carefully focused profiling program might produce valuable results, and we simply do not know 
Is it implausible that race or religion, sensibly taken into account, could add this modest increment of accuracy? If it was clear from domestic contexts that racial profiling is ineffectual as a law enforcement tool against crimes such as drug dealing or weapons possession, that would be a reason to doubt its potential efficacy as a shield against terrorism too. In a recent book, David Harris has argued that the results from domestic profiling do show that profiling is unhelpful as well as unjust. ${ }^{67}$ But the evidence he offers is more ambiguous than he maintains. In some of the areas studied, searches of racial minorities are markedly less productive than searches of whites, even though much larger proportions of potential minority targets than of whites are being searched. ${ }^{68}$ Yet this is not always so. Sometimes searches of minorities are not so much less productive than those of whites, ${ }^{69}$ and in one instance the data reflect that police computer queries about cars driven by blacks, though far from very productive, were more productive than those concerning cars driven by whites. ${ }^{70}$

how well-focused, or how successful, such programs would be in practice. Recognition of these possibilities does, however, certainly call for intense efforts to insure that any profiling programs we adopt are carefully focused, both in conception and in implementation.

67. See HARRIs, supra note 39 , at 73-90.

68. On the I-95 highway in southern New Jersey in 2000 , Harris reports, "blacks and Latinos remain 78 percent of those searched. ... Troopers found evidence in the searches of whites 25 percent of the time; they found evidence in searches of blacks 13 percent of the time, and in searches of Latinos just 5 percent of the time." See Harris, supra note 39, at 80 (citing New Jersey State Police documents).

69. In New York City, for example, "blacks were more likely to be stopped and frisked than whites, regardless of crime rate or neighborhood characteristics. . . Police made 1 arrest for every 15 white people they stopped on a suspicion of a weapons offense. For blacks, police made 1 arrest for every 17.4 persons stopped for a suspected weapons offense. For Latinos, the number was 1 arrest for every 18 weapons stops." Harris, supra note 39, at 82 (citing Elliot Spitzer, The New York City Police Department's 'Stop \& Frisk' Practices: A Report to the People of the City of New York 115 (1999) (table IB.2).

70. Harris, supra note 39, at 82-83 (citing Albert J. Meehan \& Michael Ponder, "Race and Place: The Ecology of Racial Profiling African American Motorists" (unpublished manuscript, 2001)). Harris reports that in this study of police officers' use of "Mobile Data Terminals" in their patrol cars to check on vehicles they observe, the "overall hit rate" was only $0.7 \%$, compared to a rate for random queries of $0.6 \%$, but the rate for cars driven by blacks, $1.5 \%$, was 3 times the $0.5 \%$ rate for cars driven by whites, though the authors of the study commented that " the low number of cases precludes us from drawing any meaningful race comparisons." id. at 39 (quoting Meehan \& Ponder, infra).

In a subsequently published analysis, Meehan and Ponder report that police officers' "first [mobile data terminal] queries of license plates" produced an $8.6 \%$ hit rate for drivers the study inferred were African-American, in contrast to a $6.6 \%$ hit rate for 
These varying data clearly suggest the unsurprising possibility that racial profiling is more productive in some circumstances than in others. We might expect that profiling would be most productive when it is most nuanced - that is, when it is genuinely combined with other factors, rather than being used as a crude; and usually inaccurate, proxy for criminality all by itself. That inference would be consistent with one other study cited by Harris. This study examined searches by Maryland state troopers. Blacks were searched much more often than whites - over $70 \%$ of those searched were black, compared to only $17 \%$ of drivers. ${ }^{71}$ Harris appears to view this as evidence of racial profiling, as indeed it may be (though it is conceivable that some set of nonracial factors were present more often in the case of blacks than in the case of whites, leading to more frequent searches of blacks without any basis in racial profiling). $28.4 \%$ of the searches of blacks found contraband, as against $28.8 \%$ of the searches of whites - a difference too small to be statistically significant. ${ }^{72}$ Harris observes that these success rates are remarkably high, and explains that the figures on search results may reflect that the police had already screened out those cars they had stopped that they did not believe needed to be searched. ${ }^{73}$ In other words, these searches may have been based on a combination of racial profiling and consideration of other factors making some drivers appear more suspicious than others. It could be inferred, then, that by using race plus other factors, police were able to select a much larger group of drivers, included both blacks and whites, for productive search than they would have been able to had they excluded race from consideration altogether. Put more starkly, if race was what accounted

drivers inferred to be white. Albert J. Meehan \& Michael C. Ponder, Race and Place: The Ecology of Racial Profiling African American Motorists, 19 Justice Q. 399, 419 (2002). Interestingly, the overall disparity in hit rates turns out to reflect very different disparities in two parts of the town Meehan and Ponder studied. In the part of this largely white suburb closest to a mostly African American city, the hit rate for blacks was $9.6 \%$ and for whites only $5.2 \%$, id.; in some subparts of this area, black drivers were the subject of disproportionate numbers of "queries," but the disproportions were relatively modest, id. at 416. In contrast, in areas of the white suburb further from the African American city, blacks were typically much more often the subject of queries in comparison to their proportion of the driving population, id., and in these parts of the town, the hit rate for blacks was $6.8 \%$ while the hit rate for whites was $8.9 \%$, id. at 419 . Thus while this study may indicate that a somewhat discriminatory profiling program can be moderately productive, it also points to the ease with which such programs can become much more distorted in their application and use. In this town, as the authors say, "queries are the highest for African Americans where hits are the lowest." Id. at 420 (emphasis in original).

71. HaRRIS, supra note 39 , at 79 .

72. Id. at 80 .

73. Id. at 243 n.18. 
for the fact that black drivers were selected for searches that proved productive four times as often as the black drivers' numbers in the driving population would have predicted, then racial profiling made sense.

It is by no means clear what happened in Maryland, however, and obviously not certain that what happened there could be replicated in the context of terrorism. ${ }^{74}$ We do not know that sensible profiling will lead to better identification of terrorists in 1 case out of 1000 , or even 10,000; such a result does not seem impossible, but the gains from this step will remain, perhaps forever, a matter of speculation.

We also know that "sensible profiling," if it exists at all, is likely to be hard to achieve. If we understand anything about such factors as race or ethnicity, it is that they often do not get sensibly taken into account. People's judgments about others can shift dramatically, and unnervingly, on the basis of race. ${ }^{75}$ Race (and, in current conditions, perhaps religion as well) may crowd other factors out altogether. New Jersey state troopers, for example, searched African-American drivers vastly more often than they searched whites during the heyday of highway racial profiling in the 1990s; some state troopers searched only blacks. ${ }^{76}$ Racial profiling can be a substitute for careful law enforcement; the police may "round up the usual suspects" because that is easier, cheaper and seemingly more vigilant than the painstaking, frustrating and perhaps invisible work of finding actual terrorists. ${ }^{77}$ When

74. Harris argues that to justify African Americans' cars being searched so much more frequently than those of whites, the success rates should have been higher for the searches of the cars of African Americans. $I d$. at 79-80. On the other hand, it has been argued that equal success rates from disproportionate rates of search need not reflect prejudice at all, but rather could result from an unprejudiced allocation of police resources that maximized the return from searches and, at "equilibrium," made criminality equally unattractive for each racial group. John Knowles, Nicola Persico \& Petra Todd, Racial Bias in Motor Vehicle Searches: Theory and Evidence, 109 J. Pol. Econ. 203, 227-28 (2001). Dependable data on the correlations, if any, between race and crime could resolve such disputes.

75. For example, R. Richard Banks notes that although suspect descriptions typically contain information about many factors, including race, "[1] aw enforcement officers almost always limit their search on the basis of race, even as they do not limit it on the basis of every other aspect of the description." Banks, supra note 27, at 1110 (footnote omitted).

76. Harris, supra note 39, at 57; for similar results in Maryland, see id. at 62.

77. Even if profiling produced information every bit as good as more painstaking work accomplished without profiling, we would not normally be justified in preferring to profile on the ground that it was easier and cheaper. Any number of cases have reiterated that administrative convenience is no justification for discrimination. But those cases cannot be read without any qualification. One reason to profile, in late 2002, may be that we do not yet have the baggage-screening machines that will give us 
this is true, taking race into account may add to the information law enforcement authorities possess, but it reduces the information they actually consider.

Is it impossible, then, to take race or religion sensibly, rather than abusively, into account? Certainly not. No one suggests that a police officer who obtains a detailed description of a suspect - say, that the suspect is 5'10", heavy-set, wearing a blue T-shirt and tan pants, and white - should ignore the racial portion of the description. ${ }^{78}$ In these circumstances, race is obviously relevant and obviously should be considered; however prone we are to racial stereotyping, we would be mad to ignore race here. In this and countless other similar circumstances, we must attempt to consider race without it blinding us to other relevant information; much of the time, presumably, we succeed - or, at any rate, we do not fail so egregiously as to make it plausible to try to delete race from our thoughts here. ${ }^{79}$

Moreover, it is a truism of psychology that in general it is more productive to acknowledge emotions openly and seek to deal with them than it is to try to suppress them. Forbidden thoughts find their

greater ability to do meaningful universal screening. Editorial, No Way to Fight a War, N.Y. TImEs, July 25, 2002, at A16 ("Deploying tens of thousands of new federal screeners by November is a daunting, and expensive, logistical challenge. Installing more than 1,000 of the enormous CAT-scan bomb-screening machines at airport terminals may be an even greater one."). If those machines simply can't be obtained until, say, January 1 , 2003 , it is not mere administrative convenience for us to take such steps as we can to protect ourselves until then. Even if those machines could be obtained, say, two months earlier - but only for an incremental cost of some billions of dollars - we might well be justified in forgoing the extra expense. Cf. Rostker v. Goldberg, 453 U.S. 57, 81 (1981) (upholding the exclusion of women from the draft even "assuming that a small number of women could be drafted for noncombat roles," in part because "Congress simply did not consider it worth the added burdens of including women in draft and registration plans"). Sooner or later, mere money and time must become compelling governmental interests. Thus, for example, even if we could eliminate the need for limited racial profiling by mobilizing our entire armed forces and deploying them at every site where searches were needed, I doubt that we would be constitutionally obliged to do so. As a practical matter, moreover, it is doubtful that current courts would be receptive to claims that profiling had been chosen not out of ineluctable budgetary necessity but out of mere political preference.

78. Harris, for example, agrees that "[i]t does make sense to use racial or ethnic characteristics in enforcement, but only in one context: cases in which race or ethnic characteristics describe actual suspects." HARRIs, supra note 39, at 152.

79. R. Richard Banks argues forcefully that race is misused in suspect descriptions, but he does not urge its removal. Banks, supra note 27, at 1102-04, 1109-11, 1123-24. Banks concludes that " $[t]$ here is no policy choice that would avoid the imposition of racial inequality. Any choice is a choice among inequalities. That is the tragedy of race. The possibility of truly avoiding state imposition of racial inequality is foreclosed by the pervasive role of race in American society." Id. at 1123-24. 
way to the surface somehow. It is impossible to obey the instruction "don't think about elephants." In the context of terrorism, it is similarly impossible to ignore the fact, the inescapable fact, that we have been attacked by a Muslim terrorist organization with roots in Arab states. This fact, and people's reactions to it, will shape our law enforcement response whether we acknowledge it or not. If we think it is a relevant fact, and if we want it to assist us rather than to blind us, and if we can find ways to avoid its overwhelming our judgment, we have reason to accept it as a legitimate part of what we consider in antiterrorist law enforcement. We do not know that profiling will improve law enforcement success, but it might - and so we should not dismiss this tool on the ground that it is simply useless. ${ }^{80}$

But we have not yet fully assayed the impact of nondiscriminatory, or discriminatory, law enforcement. Simply as a matter of effective law enforcement, avoiding discrimination can produce important benefits, in two ways. First, discrimination may generate grievances that ultimately flower into terrorism. That danger may be remote for most people in the United States, but we act on a world stage. When it decided Brown v. Board of Education, the Supreme Court may have been aware that one reason to overturn racial segregation was to present the United States in a better light to the world, and we are under at least as exacting scrutiny now. ${ }^{81}$ Second, and of more immediate concern domestically, discrimination may alienate Muslim and Middle Eastern communities in the United States, in much the same way that racial profiling has alienated black communities already. As Fareed Zakaria points out, the country needs the cooperation of loyal members of these communities, precisely in order to root out the few people in their midst who may actually be terrorists. ${ }^{82}$ These are important considerations. Like the claims for the law enforcement benefits to be

80. It is also plausible to think that profiling can be more accurate when it is not based on generalizations about criminal propensity - generalizations that could be correct, but are prone to tapping prejudice rather than data - but instead on observations about membership. A number of scholars have observed that criminal gangs are often not racially integrated, see, e.g., Stuntz, supra note 6 , at 2178 . It is not prejudiced to think that, of several suspects, only the one from a given gang's ethnic group is a possible member of it. Al Qaeda is not a monoracial organization, but it certainly does have membership criteria, and looking for people who fit those criteria has a foundation in fact.

81. For a chilling, recent example of the state of Muslim public opinion towards the United States, see Jane Perlez \& Raymond Bonner, Jakarta: Indonesia Orders Muslim Cleric to Undergo Questioning, N.Y. TIMEs, Oct. 18, 2002, at A14 ("Many educated Indonesians say they believe the United States was somehow responsible for the Bali [bomb] attack. There is little support for the notion that Muslim radicals with roots in Indonesia masterminded the attack.")

82. Zakaria, supra note 51; see also HARRIs, supra note 39 , at 128. 
gained from profiling, however, it is fair to say that these arguments as to its costs are speculative. We do not know how much profiling may cost us, either in general or as the result of any specific event.

We can be surer of another set of costs, which we will pay whether or not law enforcement, narrowly conceived, is undercut. Most obviously, profiling will lead to many, many searches of people who do not deserve to be intruded upon but will be, because of consideration of race and religion. These searches will be frightening and humiliating. If the experience of other street and highway profiling is a guide, they may even be dangerous to entirely innocent people who find themselves swept up in confrontations with the police. ${ }^{83}$ When we avoid profiling, we avoid imposing these terrible costs on those who would be profiled. More broadly, avoiding discrimination teaches the lesson that the government does not tolerate, much less model and encourage, discriminatory treatment. It acknowledges the bitter experience of the past with racial profiling, most recently in the abusive law enforcement practices directed at people "driving while black," 84 and reminds everyone that Muslims and Arabs are every bit as much a part of our society as other groups whose victimization is now deplored. ${ }^{85}$

So we might put the question this way: Given that we cannot ordinarily shut down the society, or treat every person with maximum vigilance, how should we trade off the values of prevention of terrorism perhaps enhanced by discriminatory searching that targets those relatively more likely to be terrorists - against the values of nondiscrimi-

83. See, e.g., David Kocieniewski, New Jersey Troopers Avoid Jail in Case That Highlighted Profiling, N.Y. Times, Jan. 15, 2002, at A1 (troopers "shot three unarmed men during a traffic stop on the New Jersey Turnpike").

84. For poignant examples of this practice, see Harris, supra note 39, at 1-10.

85. In contrast, many Arab-Americans may now feel deeply stigmatized. See, e.g., Danny Hakim, For Arab-Americans, a 7/4 for Recalling 9/11, N.Y. TimEs, July 5, 2002, at A12 (quoting Haaris Ahmad, who is "the executive director of the Michigan branch of the Council on American-Islamic Relations": "we have been branded as an other, as either a Muslim or an Arab, and that hurts ... The fact that we've been profiled and targeted, we've been told we should accept that for the sake of the security of our country, we don't think it's appropriate."); Dean E. Murphy \& David M. Halbfinger, 9/11 Bridged the Racial Divide, New Yorkers Say, Gingerly, N.Y. Times, June 16, 2002, at 25, 30 (reporting that many South Asians and Middle Easterners, unlike other New Yorkers, "described feeling a new sense of alienation in recent months"). More than half of Muslims polled recently agreed that they personally knew of "any Muslim in your area who has suffered anti-Muslim discrimination, harassment, verbal abuse, or physical attack since Sept. 11," and a quarter said that they themselves had had such experiences. Muslim America Poll, supra note 51, at 10-11. In the same poll, asked whether the government's "question[ing] thousands of Muslims in the U.S. and arrest[ing] hundreds" was necessary to protect the country or an unwarranted abuse of liberty, over three fifths expressed agreement that it was an abuse. 
nation - confirmed by treating all persons equally even with regard to security precautions?

The answer, I think, is that there isn't just one answer to this question. Racial profiling may make a real contribution to protecting us from terrorism, but it also is profoundly costly, to its immediate targets and ultimately the entire society. Moreover, we cannot measure precisely either its costs or benefits; we can only attempt to gauge what makes most sense in the dangerous circumstances in which we live. The correct resolution of this dilemma, I suggest, is neither prohibition nor wholesale acceptance, but rather a recognition that profiling can in some circumstances be an appropriate, though never welcome, tool of protection against terrorism. Starting from the premise that ordinarily profiling is unacceptable, we must seek to define the limited exceptions to this rule, by assessing the peril faced, the alternatives for facing it, and the impact of profiling in those circumstances, both for good and ill.

In the situation I imagined, the peril is great and the alternatives inadequate. A building has just been successfully attacked and a caller who claims responsibility for the attack is credibly threatening imminent additional attacks. This is an emergency. We have no possible complete protection against it, because our resources are inescapably limited, and so we will, inevitably, have to rely on imperfect proxies for dangerousness in some of the efforts we make to head off the possible next attack. Among those proxies, it seems rash to ignore those immutable factors that may, in fact, be of significant value.

Here, the proxy is carefully chosen, both in terms of who it subjects to special attention and how it operates. The proxy involved here - Middle Eastern origin and Muslim religious faith - is precisely linked to the identity of the suspected terrorists, a Middle Eastern group known for its extremist Muslim politics. Moreover, it deserves emphasis that - as Stuart Taylor has proposed ${ }^{86}$ - the profiled group

86. See Taylor, supra note 45. In this essay, Taylor modifies his own earlier proposal for profiling of "Arab-looking" people, and instead advocates "profiling based on apparent origin in any of the nations known to be exporters of anti-American terrorism - not only nations in the Arab world, but also most, or all, of the nations in the Muslim world." He maintains that "[m] illions of Arab-Americans would not fit the profile because their American roots would be apparent - from their accents and speech patterns - to trained security screeners." It is a virtue of this proposal that it profiles more precisely - it is, in equal protection terms, more "narrowly tailored" - but it would be quite unrealistic to believe that those profiled will include only people who are not American citizens or lawful permanent residents. Many Muslim Americans are themselves foreign born; in a recent poll, "[s]eventy percent of respondents were born abroad, though ninety percent are American citizens," Muslim America Pol., supra note 51 , at 4 , and would be subject to special law enforcement scrutiny under this pro- 
is not all Muslims, or all foreigners, or even all Muslim foreigners from the very large number of countries where $\mathrm{Al}$ Qaeda has a presence. This proxy seeks to identify those most likely to be terrorists; it excludes others, from Muslims in general to Americans in general, who conceivably might be terrorists and focuses only on the most plausible group. ${ }^{87}$

It is important to recognize, in addition, that here the proxy of Middle Eastern background and Muslim religion is not intended either to lead automatically to search when it is present or to preclude search when it is absent. Many factors may play a part in a terrorist profile meant to identify those few people who are, in some way, more suspicious than others. In other words, this is not a profile relying solely on ethnic or religious characteristics, of the sort I have already criticized; instead, it is a profile meant to encompass ethnicity and religion together with other relevant characteristics. I do not doubt that application of this profile will frequently focus on those who fit the ethnic and religious criterion, even where there is little other reason for suspicion, and indeed inclusion of this criterion is meant to allow such decisions. In practice, anxious screeners will probably sometimes focus on those who fit this criterion even when no other basis for suspicion is truly present. But the profile does not support their doing so automatically. For example, small children from this group are no more suspicious than my daughter was when she was searched. And the profile should be able to identify others, outside this group, who also need to be searched (in addition to those people, also outside this group, who are selected for search on purely random grounds).

Could this argument be pressed even further, to maintain that the search program we are considering is not truly an instance of profiling at all, but is rather an example of diligent pursuit of people fitting an actual suspect description? I would not see it this way. The underlying suspect description is scanty, embracing at most the gender, ethnicity, religion and political affiliation of the suspects. Moreover, the application of this profile, with its important ethnicity-plus-religion factor, is likely to be quite indiscriminate. The truth is that the police, in this

posal. There is also clearly room for mis-identification of people as Muslims, and as Middle Easterners (even assuming agreement on the geographic dimensions of the Middle East), although in my example the chance of mis-identification is somewhat reduced because the first, universal step of the screening process will be checking identification for every building entrant.

87. I do not offer this example as the only legitimate profile that might be used. What is legitimate depends on the circumstances. If, say, intelligence information suggested that this Middle Eastern group was now working closely with a Pakistani terrorist group, as Al Qaeda may be, then it might well be appropriate to expand the targeted group to include Pakistanis. 
example, know very little about who, exactly, threatens New Yorkers' safety. For that reason, they are undertaking massive interventions, in which most of the people subjected to scrutiny will be entirely innocent. Though the program is meant to have some degree of nuance, it is more concerned with the protection of public safety than with the investigation of crime, and is properly seen as an instance of racial and religious profiling.

It should concern us that the vast majority of the people searched on the basis of their ethnicity and religion will be entirely innocent. Yet it seems likely that the potential stigma and humiliation involved in such emergency responses will be attenuated by the context in which they take place. Everyone will be subject to many impositions, and some people will be selected, either randomly or on the basis of other profile factors, for specially burdensome steps - here, the searches at building entrances. Those who are racially profiled and therefore also selected for specially burdensome steps will be burdened indeed, but not uniquely. In addition, for most people who are singled out for special attention the intrusion will be brief, courteous and uncontentious. ${ }^{88}$ The isolation and potential danger in highway stops and street stop-and-frisks should be absent. These intrusions are not trivial, but their impact should not be exaggerated either. Moreover, everyone will share the sense of imminent peril, and perhaps some measure of patience with the inevitably imprecise steps that are all we can take to guard against it. And, finally, if such blunt discrimination is confined to emergencies, then we will not be setting into motion the sense of daily, grinding humiliation that is so much a part of the problem of racial profiling in domestic law enforcement.

Surely the need is greatest, and the harm least, if profiling is confined to emergencies or other situations as exigent as emergencies. Before considering what these "other situations" might be, let us look at the meaning that "emergency" itself should have. This term is not, after all, a self-defining one. On the contrary, it is a term subject to abuse, as the grisly history of states of emergency in many nations at-

88. The abusiveness of many police profile stops seems to play a significant role in making these events so disturbing. Cf. HARRIS, supra note 39 at 112-13 (describing the "survival workshops" for young people run by "100 Blacks in Law Enforcement Who Care" in New York). William Stuntz argues that "it is the manner of the stop - the degree of disrespect and force the officers display - that largely determines how the suspect will react: with mild embarrassment, or with rage," Stuntz, supra note 6, at 2173, and on this basis argues for regulation focused on the manner in which profiling stops are carried out. $I d$. at 2169-79. I do not assume that anti-terrorist profiling will be free of discourtesy, but there is every reason for law enforcement agencies - and courts, as Stuntz urges - to work systematically to prevent abuse. 
tests. ${ }^{89}$ But if the term is hard to define, it is also hard to ignore; emergencies do occur in the life of nations, as of people, and in them conduct is appropriate, even necessary, that would otherwise be unacceptable. International covenants recognize the legitimacy of emergency power, ${ }^{90}$ and even a nation as sensitive to the abuse of emergency power as post-apartheid South Africa has chosen to make explicit provision for emergency authority in its new constitution. ${ }^{91}$

We have no general provision for emergency power in our constitutional order, but our governments have certainly exercised emergency powers. ${ }^{92}$ It need not be beyond the capacity of our courts to recognize that in certain limited circumstances, searches based on racial or religious or gender profiling are legitimate - even though in general they are not legitimate at all. The first step is to define a terrorist emergency. This can be done, straightforwardly enough, by charac-

89. See Stephen Ellmann, A Constitution for All Seasons: Providing Against Emergencies in a Post-Apartheid Constitution, 21 Colum. Hum. Rrs. L. Rev. 163, $167-69$ (1989).

90. See id. at 180 n.52 (citing, inter alia, International Covenant on Civil and Political Rights, opened for signature Dec. 19, 1966, art. 4, 999 U.N.T.S. 171, 6 I.L.M. 368, 36970).

91. S.A. Const. $\$ 37$ (1996). South Africa follows the International Covenant on Civil and Political Rights, supra note 90 , art. 4, in providing that even when a state of emergency has been declared, certain constitutional rights are "non-derogable." See S.A. Const. $\$ 37(5)$ (c). Among these is the protection against discrimination, although - in language closely tracking the International Covenant, supra, art. 4(1) - South Africa chose to prohibit, in emergencies, only a portion of the discrimination it ordinarily proscribes. As the "Table of Non-Derogable Rights" following section 37 of the constitution provides, the right to equality is protected " $[w]$ ith respect to unfair discrimination solely on the grounds of race, colour, ethnic or social origin, sex, religion or language." This language could be read to authorize discrimination that is partly on the basis of race or the other listed factors, but it is more likely that this provision means to bar all discrimination stemming from these factors that would otherwise be barred, but "solely" discrimination based on these factors rather than the others, such as sexual orientation, that the normally applicable equality provision also addresses. S.A. Const. $\$ 9$. Even that provision, moreover, is not an absolute bar on racial discrimination; like our constitution, but more explicitly, this section of South Africa's constitution prohibits only "unfairly discriminating." Id. $\$ 9(3)$ (emphasis added). It is hard not to think that if South Africa faced a terrorist emergency at the hands of Afrikaner white supremacists, it might justly undertake racial profiling directed at this group. Cf. Boer Nation Warriors Planted Bombs, MaIl \& Guardian Online (South Africa) (Nov. 11, 2002), available at http://www.mg.co.za/Content/13.jsp?0=11867 (last visited Nov. 11, 2002).

92. Although the constitution does include some provisions for emergency action, notably the authorization of suspension of the writ of habeas corpus, U.S. ConsT., art. I, $\$ 9$, cl. 2, our constitutional strategy for emergency powers is largely one of "textual silence," with the courts somewhat inconsistently filling in what the constitution itself does not state. See Ellmann, supra note 89, at 171-79. 
terizing it as a situation in which we have a substantially based fear of imminent terrorist attack on the nation or its people. ${ }^{93}$

It is true that the concept of "a substantially based fear of imminent terrorist attack" can be construed loosely or narrowly. I urge that it be understood strictly, and that courts be prepared both to recognize its existence and to police its boundaries. ${ }^{94}$ Courts will not be able to perform this task on their own, however, and it is essential that government officials and law enforcement agencies commit themselves equally to these principles. It is now over a year since New York and Washington were actually attacked. There have been many announcements of threats since then, but none, so far as we know, that has had the foundation and specificity of the threat in the example I have imagined ${ }^{95}$ It is important to have the courage and clarity of vision to distinguish between dangers and threats on the one hand, and crises on the other. We in New York, and elsewhere in the nation, are still in some danger, and we are at war, but we are not in a terrorist emergency. Outside of emergency, the necessity for discriminatory action lessens.

What should guide our definition of emergency, of course, is an understanding of the consequences that flow from the definition we adopt. The reason for defining it stringently is not solely because there are, in fact, degrees of danger. It is also because we live in a dangerous world, and in this world a definition of emergency that essentially placed us in a permanent state of emergency would also place us permanently in a state of marginal respect for civil liberties. We know the world is more dangerous than we once thought, but we must try to find a way to live as a free people in this world - rather than waiting for

93. Compare the South African specification of the grounds for declaring a state of emergency: "when (a) the life of the nation is threatened by war, invasion, general insurrection, disorder, natural disaster or other public emergency; and (b) the declaration is necessary to restore peace and order." S.A. Const. $\$ 37(1)$. Though I once endorsed the "threat to the life of the nation" standard, Ellmann, supra note 89 , at 184 , this formulation does not reflect the malevolent character of terrorism, which might threaten the life of the nation but could also "merely" cost large numbers of lives, without in any real sense threatening the nation's survival.

94. South Africa's constitution provides that "[a]ny competent court may decide on the validity of (a) a declaration of a state of emergency; . . . or (c) any legislation enacted, or other action taken, in consequence of a declaration of a state of emergency." S.A. Const. \$ 37(3); see Ellmann, supra note 89, at 187-89.

95. We are in fact in a state of emergency, declared by President Bush. Declaration of National Emergency by Reason of Certain Terrorist Attacks (Sept. 14, 2001), available at http://www.whitehouse.gov/news/releases/2001/09/20010914-4.html (last visited Aug. 8, 2002). This declaration does not mean, however, that every day that passes is a day of terrorist emergency of the sort that I am arguing could justify racial profiling. 
the restoration of an idyllic security that may be long in coming. There may come a time when we no longer have this luxury - when we are under such unremitting and resourceful attack that we cannot lower our guard for a moment. Perhaps Israel is in this situation today. But we are not there, and should not imagine ourselves to be.

There is another reason to insist on the distinction between emergencies and lesser dangers. This reason is well illustrated by one of the most egregious failures to make this distinction in our history, the forced relocation and internment of Japanese-Americans during World War II. The United States has now apologized for these events, as it should have. ${ }^{96}$ But it is important to look back at them now, in order to understand what exactly went wrong, and to assess what risk we now run of going equally wrong again.

The country was at war against Germany, Italy and Japan. It was not irrational to be concerned that citizens of those three nations who lived in the United States might harbor loyalties to their homelands. ${ }^{97}$ Nor was it absurd to think that even some U.S. citizens of German, Italian or Japanese ancestry might harbor such feelings. Since the United States had treated Japanese people especially badly, it was also not unreasonable to fear that some of the people we had so mistreated might be prepared to act on their justifiable anger. ${ }^{98}$ Certainly we were responsible for that mistreatment, but in 1942 the country needed to deal with the peril it faced, even that portion of the peril for which it was itself responsible. And after the successful Japanese attack on Pearl Harbor, the idea of an invasion of the Hawaiian islands was not inconceivable - and after Hawaii might have come the mainland's Pacific coast. ${ }^{99}$

96. Civil Liberties Act of 1988, 50 U.S.C. $\$ 1989$ (2002).

97. A.W. Brian Simpson has noted that "[b]oth Great Britain and the United States detained or exercised lesser forms of control over noncitizen enemy aliens," A.W. Brian Simpson, Detention Without Trial in the Second World War: Comparing the British and American Experiences, 16 FLA. ST. U.L. REv. 225, 230 (1988). The 1942 curfew order upheld in the Hirabayashi case applied not only to U.S. citizens of Japanese descent, such as Hirabayashi himself, but also to "all alien Japanese, all alien Germans, [and] all alien Italians." Hirabayashi v. United States, 320 U.S. 81, 88 (1943).

98. Hirabayashi, in a footnote, details a range of federal, state and societal discrimination against people of Japanese descent, and in text the Court observes, more opaquely, that " $[\mathrm{t}]$ here is support for the view that social, economic and political conditions which have prevailed since the close of the last century, when the Japanese began to come to this country in substantial numbers, have intensified their solidarity and have in large measure prevented their assimilation as an integral part of the white population." Hirabayashi, 320 U.S. at 96 \& n. 4.

99. As Hirabayashi put it, "Although the results of the attack on Pearl Harbor were not fully disclosed until much later, it was known that the damage was extensive, and that the Japanese by their successes had gained a naval superiority over our forces in the 
What made our nation's treatment of the people of Japanese descent, citizens and non-citizens, unjust was not that we entertained some concern about their loyalty. The central injustice, rather, lay in how wildly we exaggerated those concerns, and how brutally and sweepingly we reacted to them. It now seems very clear that prejudice against people of Japanese descent sharply intensified suspicions directed at them ${ }^{100}$ and quite despicable greed - for the homes and businesses the internees had to sell at bargain prices as they were forced to enter the camps - also played a part. ${ }^{101}$ Moreover, while prudent military planners certainly had to reckon with the possibility of Japanese attacks on the United States, there was no emergency; attack was not imminent and, at least after the shock of Pearl Harbor had faded, this was probably reasonably clear. When fears are exaggerated, other motivations - prejudice pure and simple - can find a home as well, and so it is crucial not to indulge in such exaggeration. ${ }^{102}$

Meanwhile, we had an alternative to the cruel relocation program we imposed. That was to assess the loyalty of those we were concerned with on an individual basis. In fact, the government had compiled a list of 2000-3000 individuals before the war began — but rather than focusing on individuals our nation chose to target an entire racial group. ${ }^{103}$ In Britain, meanwhile, with the Nazis across the English

Pacific which might enable them to seize Pearl Harbor, our largest naval base and the last stronghold of defense lying between Japan and the west coast." Id. at 94.

100. Justice Murphy, dissenting in Korematsu, quotes the Final Report by Lt. General J. L. Dewitt, who commanded the Western Defense Command, on the removal of people of Japanese descent from the Pacific area. "In it," writes Justice Murphy, "he refers to all individuals of Japanese descent as 'subversive,' as belonging to 'an enemy race' whose 'racial strains are undiluted,' and as constituting 'over 112,000 potential enemies . . . at large today' along the Pacific Coast." Korematsu v. United States, 323 U.S. 214, 236 (1944) (Murphy, J., dissenting). Later in his dissent Justice Murphy argues that the reasons offered for the "forced evacuation" seem "to be largely an accumulation of much of the misinformation, half-truths and insinuations that for years have been directed against Japanese Americans by people with racial and economic prejudices - the same people who have been among the foremost advocates of the evacuation." Id. at 239 (Murphy, J., dissenting).

101. Justice Murphy observes that "[s]pecial interest groups were extremely active in applying pressure for mass evacuation," and quotes one representative of vegetable growers and shippers who "frankly admitted that 'We're charged with wanting to get rid of the Japs for selfish reasons. We do. It's a question of whether the white man lives on the Pacific Coast or the brown man," Id. at 239 n.12 (Murphy, J., dissenting).

102. Simpson demonstrates that the "scale and duration of detention" of citizens were "much greater" in the United States than in Britain, and explicitly attributes the difference to "that evil force, racial antagonism." Simpson, supra note 97, at 265.

103. See Simpson, supra note 97 , at 238, n.51. This list itself seems to have been over-inclusive, although there evidently was an actual Japanese spy ring, which investiga- 
Channel rather than across an ocean, the British government not only interned far fewer citizens than we did, but also treated enemy aliens in a much more individualized fashion. ${ }^{104}$ Individualized treatment was possible, but we did not try to provide it. ${ }^{105}$

The emergency profiling I am endorsing here is far, far less intrusive than the internments of World War II, and it is explicitly targeted for situations where alternative law enforcement techniques truly are unavailable or inferior. Nevertheless, one might oppose even this use of profiling on the ground that it is one step in a progression that could ultimately lead, as it did in World War II, to mass detentions of American citizens and residents on the basis of race. Moreover, it is not the only such step, for if our government disclaims discrimination in ordinary law enforcement, it unambiguously employs national origin as a basis for targeting people in the context of immigration. ${ }^{106}$

This is not a fanciful concern. Discrimination, even violence, against Arab-Americans rose significantly after September 11th. ${ }^{107}$

tors broke up in mid-1941. See Peter Irons, Justice at War: The Story of the Japanese American InTERnment Cases 22-23 (1983). A measure of how excessive the West Coast internment program was is that while it was going on, the army general who took over command in Hawaii itself ten days after Pearl Harbor "resisted pressures for the mass internment of Japanese" there, where they "made up more than a third of the population." Id. at 269.

104. Simpson writes that although Britain "adopted a wholesale policy of interning enemy aliens" in June 1940, when the war was going very badly indeed, by the end of that same year "the policy had in effect been reversed, and in the course of the next year large numbers of aliens were released while a serious attempt was made to separate out the minority who could, rationally, be viewed as a threat." Id. at 230-31. See also Korematsu, 323 U.S. at 242 n.16 (Murphy J., dissenting) (describing the individualized consideration of the cases of "approximately 74,000 German and Austrian aliens" by British authorities over a six-month period early in the war, resulting in the unconditional release of 64,000 ).

105. While the United States was interning all people of Japanese ancestry, citizen and non-citizen alike, from the West Coast, we also arrested some 12,000 enemy aliens during the first year of World War II, presumably in all parts of the country. Individual hearings were provided to these arrestees but, according to Peter Irons, "[f]ewer than half of the Germans and Italians were interned after their hearings. In contrast, more than two-thirds of the Japanese aliens remained in internment camps during the war." Irons, supra note 103, at 24.

106. See supra note 17; see also infra text accompanying notes 127-53 .(discussing the government's interview program targeting holders of non-immigrant visas from countries with Al Qaeda activity).

107. Hussein Ibish, Communications Director for the American-Arab Anti-Discrimination Committee, commented in May 2002 that "[f]ollowing September the 11th, we confirmed over 700 violent incidents involved in the backlash against Arab-Americans." (He went on to say that "that number has been steadily declining.") CNN Late Edition with Wolf Blitzer, supra note 43 . It is quite possible that there were additional, unre- 
Even if support for profiling of the kind I am advocating is not itself a mark of unjust discrimination, ${ }^{108}$ one poll has apparently found that a third of Americans support "allowing the U.S. government to take legal immigrants from unfriendly countries to internment camps."109 Another poll reports that most Americans favor closing the border to all would-be entrants from Arab countries. ${ }^{110}$ Both political and religious leaders have also made stigmatizing, sometimes crudely biased, comments about Muslims. ${ }^{11}$

ported incidents. In the Muslim America Poll, supra note 51 , at 10 , only $21.1 \%$ of respondents were aware of anti-Muslim "discrimination, harassment or attacks . . in your area" before September 11, while $59.5 \%$ were aware of such incidents since September 11.

108. In a recent poll, $54 \%$ of respondents approved of "using racial profiling to screen Arab-male airline passengers," while $34 \%$ disapproved and $12 \%$ were not sure. Roper Center at University of Connecticut, Public Opinion Online, accession number 0406814, question number 022 (polling done June 4-5, 2002) (Fox News, Opinion Dynamics Poll) (available in LEXIS, BUSREF Library, RPOLL File).

109. See Jeffrey M. Jones, Poll Analyses: The Impact of the Attacks on America: Americans Expect a Long and Difficult War, Gallup News Service, Sept. 25, 2001, available at http:// www.gallup.com/poll/releases/pr010914c.asp (last visited Nov. 7, 2002); Volpp, supra note 51 , at 1591 n.68.

110. $53 \%$ of respondents said that "[d]uring the war on terrorism" they favored "[s] ealing US (United States) borders and stopping all immigration of young Arab men while the search for terrorists is conducted." Roper Center at University of Connecticut, Public Opinion Online, accession number 0404843, question number 021 (polling conducted May 14-15, 2002) (Fox News, Opinion Dynamics Poll) (available in LEXIS, BUSREF Library, RPOLL File).

111. Representative John Cooksey, for example, has commented that "any person who has 'a diaper on his head and a fan belt wrapper around the diaper' needs to be singled out for questioning." Dennis Camire, Muslim Council Seeks Action Against Cooksey for Slur, Gannett News Service, Sept. 21, 2001, available at 2001 WL 5112923 (quoted in Volpp, supra note 51, at 1580 n.13). Professor Volpp also cites Attorney General John Ashcroft's statement that "Islam is a religion in which God requires you to send your son to die for him. Christianity is a faith in which God sends his son to die for you." Volpp, supra, at 1582 n.20 (citing Katha Pollitt, Egg on the Brain, Nation, Mar. 4, 2002, at 10). Rev. Pat Robertson has declared that Islam "is not a peaceful religion that wants to coexist. They want to coexist until they can control, dominate and then if need be destroy." Alan Cooperman, Robertson Calls Islam a Religion of Violence, Mayhem, WASH. Post, Feb. 22, 2002, at A2. Franklin Graham, son of Rev. Billy Graham, in late 2001 called Islam "a very evil and wicked religion." Michael Wilson, Evangelist Says Muslims Haven't Adequately Apologized for Sept. 11 Attacks, N.Y. TIMEs, Aug. 15, 2002, at A14. Still more recently, Rev. Jerry Falwell called the prophet Muhammad a "terrorist" on the television program 60 Minutes, "setting off Hindu-Muslim clashes in India that left at least nine people dead." He subsequently said that "he meant no disrespect to "any sincere, law-abiding Muslim.'" Muslims Welcome Falwell's Apology, N.Y. TIMES, Oct. 14, 2002, at A9. 
But this is not the full picture. Both government officials and private citizens have also spoken out in support of Muslims and against discrimination. ${ }^{112}$ Hate crimes against Arab-Americans have apparently returned to pre-September 11 levels, ${ }^{113}$ and Americans express little sympathy for the idea that anti-Muslim violence is excused by the September 11 attacks. ${ }^{114}$ When a member of the U.S. Civil Rights Commission predicted that internment could follow another terrorist attack on the country, he was sharply attacked and hastened to say that he was only expressing concern about a prospect he himself deplored. ${ }^{115}$

It is striking, in this context, to consider the reaction to the Bush Administration's plan to use military tribunals to try terrorists. As Jack Goldsmith and Cass Sunstein have demonstrated, the Bush proposal has met far sharper criticism than Franklin Roosevelt's actual use of

112. President Bush told Congress and the nation on September 20, 2001 that " $[t]$ he terrorists practice a fringe form of Muslim extremism that has been rejected by Muslim scholars and the vast majority of Muslim clerics - a fringe movement that perverts the peaceful teachings of Islam." He went on to "speak . . . directly to Muslims throughout the world," saying "We respect your faith. It's practiced freely by many millions of Americans, and by millions more in countries that America counts as friends. Its teachings are good and peaceful, and those who commit evil in the name of Allah blaspheme the name of Allah." President Declares "Freedom at War with Fear" (Sept. 20, 2001), available at http://www.whitehouse.gov/news/releases/2001/09/200109208.html. Leti Volpp cites other steps taken by President Bush to similar effect, though she is very skeptical about their impact. Volpp, supra note 51, at 1581. An April 2002 poll of American Muslims found that almost half of those asked felt that "government officials, non-Muslim religious leaders or other prominent people [had] publicly expressed support for the Muslim community or spoken out against anti-Muslim abuses," and that more than two-thirds had received personal expressions of support from nonMuslims. Muslim Americi Poll, supra note 51, at 11.

113. See supra note 43.

114. In mid-September 2001, a poll asked Americans about their reaction to the many acts of vandalism and threats against "Muslim and Arab citizens" since the September 11 attacks. $64 \%$ called these events "inappropriate and inexcusable"; $32 \%$ considered them "inappropriate but understandable considering the severity of the attacks on the US"; and just $4 \%$ were willing to say that these events were "an acceptable way to respond to the attacks on the US." (1\% did not have an opinion or refused to answer.) Roper Center at University of Connecticut, Public Opinion Online, accession number 0390102, question number 029 (poll conducted Sept. 15-17, 2001) (Wirthlin Quorum Poll) (available in LEXIS, BUSREF Library, RPOLL file).

115. See Lynette Clemetson, Arab-Americans: Civil Rights Commissioner Under Fire for Comments on Arabs, N.Y. Times, July 23, 2002, at A14 (quoting comments of Commissioner Peter N. Kirsanow: "If there's another terrorist attack, and if it's from a certain ethnic community or certain ethnicities that the terrorists are from, you can forget civil rights in this country," and describing subsequent controversy). 
tribunals in World War II. ${ }^{16}$ Goldsmith and Sunstein argue that one cause of the difference is the tremendous flowering of human rights jurisprudence since the Second World War, a flowering that was, if anything, cemented by the national disillusionment with the Vietnam War. ${ }^{117}$ Certainly not everyone in the country equally embraces these human rights views. ${ }^{118}$ Whatever our national differences on civil liberties, however, we have reached the point where opposition to racism is a conventional, if often half-hearted, American value. I think it is unlikely, therefore, that we are on a course that will inexorably lead us towards internments. ${ }^{119}$ The issues that realistically face us have to do not with such flagrant and past injustices but with less dramatic policies, some just, some unjust, that all require us to make difficult decisions about public safety and equality. Among these, I suggest that emergency profiling is a legitimate step - while some other steps, to which I turn below, are not. ${ }^{120}$

116. Jack Goldsmith \& Cass R. Sunstein, Military Tribunals and Legal Culture: What a Difference Sixty Years Makes, 19 Const. Commentary 261, 263-71 (2002).

117. Id. at $282-84$.

118. Goldsmith and Sunstein note that the public at large "supported the Bush military commission proposal by a greater than 2-1 margin," though even this "is more ambiguous and less enthusiastic than the public support Roosevelt received in 1942." "But," they continue, "the real differences in reaction were in Congress and especially the mainstream press and members of the legal academy. These institutions reacted with vehement, and sometimes strident, opposition." Id. at 272.

119. It has been said that the path to internment of Japanese-Americans in World War II was eighteen months long; we are not yet that far from September 11, 2001 and we might, this argument suggests, still be on the path that was followed in the 1940s. But this recollection of World War II is wrong. In fact, the curfews on the West Coast began 4 months after Pearl Harbor, and the exclusion orders took effect only two months after that, in May 1942. See Korematsu, 323 U.S. at 226-29.

120. Even if this general proposition is accepted, there remain important questions about the proper roles of the various branches of government in establishing and implementing the kinds of profiling I am defending. I will not explore these questions in depth here, but I offer these initial observations. First, authority to profile in emergencies might be found in general statutes empowering law enforcement authorities to act, despite the absence of explicit authorization, but it would certainly be preferable for the political branches of government to address this issue explicitly and in advance. Whether by statute or by regulation, those branches of government - and through them the public - should decide whether profiling is needed, and in what sorts of circumstances, and their decisions should be subject to challenge in court. Second, the exercise of these powers should be announced. I do not mean that the exact terms of profile programs should be disclosed in advance (if at all), but rather that the existence of an emergency in which the government invokes its profiling powers should be a matter of public record. Third, the actual exercise of these powers must be subject to judicial scrutiny, both with respect to whether an emergency existed and to whether the use made of the emergency profiling powers was justifiable in the circumstances. I would expect such scrutiny to be sensitive to the danger of disclosing sensitive informa- 


\section{How and How Not to Extend the Emergency Principle}

Are there any other situations as exigent as emergencies? Can they be acknowledged without essentially eliminating the exceptional character of emergencies? I think that it should be possible to identify a limited number of circumstances where peril is so great that even in the absence of a substantially founded threat of imminent attack, emergency-like precautions should be taken. Obviously, our society is full of points from which peril could flow. Many of these, however, can be protected meaningfully with individualized screening - our germ warfare research labs, for example, or nuclear reactors. Profiling is unnecessary when individualization is possible. Profiling is also unnecessary when the peril is relatively contained. We do not need to profile at the doorways of our large buildings on a daily basis, because readily available steps - such as searches of all large packages - appear to keep the threat of disaster relatively contained. ${ }^{121}$ Finally, there may be situations where we simply cannot feasibly undertake even a profiling program - for example, at the entrances to tunnels at rush hour.

What is left? Perhaps, currently, only a single circumstance: airports. ${ }^{122}$ Airplanes, as we have learned, can be quite easy to take over. Once taken over, they have the unpleasant ability to become guided missiles. And we know that our adversaries know all this very well, and

tion; I would also expect it to be deferential on the merits, especially if the courts are called upon to enjoin ongoing programs rather than to assess the constitutionality of particular criminal convictions after the emergency is over. But it is important that the recognition of emergency power not degenerate into a blank check, and so the courts have a role to play.

121. Contained, that is, under "ordinary" circumstances. In an emergency of the sort I've imagined here, we would probably be trying to protect more buildings than are currently protected, and we might need to take much more intrusive steps, moving, for example, from searching packages to searching people's bodies for explosives.

122. Stuart Taylor emphasized the special need to profile in air travel, and I agree with him on this point. Stuart Taylor, D.C. Dispatch: The Case for Using Racial Profiling at Airports (Sept. 25, 2001), available at THE ATLANTIC OnLINE, http://www. theatlantic.com /politics/nj/taylor2001-09-25.htm (last visited July 24, 2002). But I do not agree with his suggestion that profiling is justifiable only in the air travel context. $I d$. Emergencies can take many forms. The World Trade Center was destroyed by planes, but it was almost blown up by a truck bomb in its basement. See Dave Williams, The Bombing of the World Trade Center in New York City, INT'L Crim. Police Rev. (1998), available at http:// www.interpol.int (last visited July 31, 2002) (noting that "[d] uring the initial assessment of explosive damage to the complex [in 1993], it became very clear that the structural integrity of Trade Tower Number One was at risk, and that the Vista Hotel would probably collapse within days if structural steel support was not in place as. soon as possible"). 
have no compunctions about acting on what they know. Moreover, here, in contrast to some of the other potentially dangerous situations we face, it is actually possible to undertake the kinds of inquiries and searches that can increase our safety (albeit at the cost of sometimes maddening delays). In addition, all air passengers are accustomed to a measure of intrusion, and a program that subjected some people randomly selected to the same special steps as those identified on the basis of profiling would lessen the stigma to those chosen on the latter grounds. ${ }^{123}$

It is worth saying a little more about what should and should not be permitted in airport screening. First, the searches should be based on profiles rather than on prejudice. There have been a number of incidents of what appears to be pure prejudice - incidents in which, for example, passengers express anxiety about Muslim fellow travelers, and the Muslims are removed from one flight and then simply put on another. This is pandering to fear rather than protection from danger. ${ }^{124}$ As in the case of the building searches I have imagined, the profile characteristics should be chosen to be as narrowly tailored to the danger as possible, and the searches should normally be courteous and quick. Only if such straightforward steps as a search of hand luggage or routine questions (for example, about the purpose of the traveler's trip) or other, behavioral profile features such as the lack of a round-trip ticket produce reason for further suspicion should more burdensome steps be taken, such as the search of the passenger's checked baggage. ${ }^{125}$ Profiles are not very good clues to danger, and

123. There are, unfortunately, other weapons, potentially of quite comparable ferocity, that are perhaps even more readily accessible than airplanes - notably, trucks carrying hazardous materials. For example, "[a]bout 50,000 trips are made each day by gasoline tanker trucks, many of which hold as much fuel as a Boeing 757 jetliner. . . Experts said that chemicals present an even greater risk, particularly chlorine and cyanide, which can form clouds of deadly fumes." Trucks in U.S. Pose Risk as Terrorist Weapons, Experts Say, CHI. TRiB., Oct. 20, 2002, at 16, available at 2002 WL 101653377. Current security measures for trucks are far from adequate, $i d$. Whether profiling would be necessary or even useful to improve security in this area, however, and whether it could be implemented in as unintrusive a way as airport profiling can be, are questions I do not attempt to answer here.

124. See supra note 51.

125. Once the technology for screening all checked baggage is in place and in use, presumably there will be even less reason for actual opening of luggage belonging to passengers who have cleared the less intrusive steps without incident. It may be some time, however, before the machinery for universal baggage checks is up and running. See supra note 77 . 
they should not be used by themselves as a basis for more than limited intervention. ${ }^{126}$

Does this approval of emergency profiling, and even some profiling outside of emergencies, mean that anything goes? Not if it is applied in the careful way that I urge. Consider, in this light, another example of profiling, one that reflects both different threats and a different governmental response than we saw in the first case:

* The government receives what it considers credible information that a group of Muslim men plan to blow up a target in New York the next day. The government begins random searches of people it believes are Muslim men.

It is not clear whether this amounts to an emergency, since some credible information will turn out to be wrong; on the other hand, it is possible that the danger here is actually greater than in the example of a threat to blow up buildings, where the terrorist group had already struck and might only have been blustering in its phone calls to the media. Let us grant that this is an emergency, then, while also recognizing that the proliferation of credible threats is a potential source of just the sort of exaggerated perception of emergency that needs to be guarded against.

Assuming it is an emergency, however, it is not the same sort of emergency as the previous one. The authorities have, as far as the facts given indicate, no idea what sort of target the terrorists have in mind. As a result, the security measures the government takes are not focused on protecting particular targets - buildings - nor are they limited to people who obviously could be a threat to those targets - the people entering them. Here, in contrast, the government has in effect said that all Muslim men (including many people born and raised in the United States) are a threat anywhere and anytime, a more sweeping and stigmatizing assertion than any embodied in the building entry searches described above. Obviously this is wildly overinclusive. Moreover, the government has apparently not undertaken to subject other people to any security measures whatsoever; that underlines the extent to which Muslim men are being singled out and it is, in addition, clearly underinclusive - since there may well be some terrorists who are not Muslim men at all. In addition, the government has begun searching Muslim men anywhere and anytime, a much more intrusive step than searching only those people entering particular buildings.

126. For a vivid example of what should not be done on the strength of profiling alone, see HARRIS, supra note 39, at 208-18 (describing a U.S. Customs profiling program that targeted black women as suspected drug smugglers). 
There are, indeed, Muslim men who are ready and willing to commit acts of terrorist mass murder against the United States, and this fact is not irrelevant. The policy described here, however, is founded not in grim law enforcement calculation but in stereotype. As such, it should not be permitted. Actions that flow from stereotype are not saved from unconstitutionality by the existence of some factual basis for the stereotype.

\section{Community Profiling: The Interview Program}

The principles that support acceptance of emergency profiling also suggest the unacceptability of another discriminatory program, one that is definitely not hypothetical:

- The government decides to conduct voluntary interviews with approximately 5000 men aged 18 to 33 who recently entered the United States with student, tourist or business visas. ${ }^{127}$ The 5000 are chosen based on their having arrived here from "countries with suspected terrorist links," rather than on their being citizens of those nations. ${ }^{128}$ But it seems very likely that most people arriving from countries with $\mathrm{Al}$ Qaeda connections will actually be nationals of those countries, and therefore that this program is in effect, if not in intent, a program largely targeting young male visitors from particular countries. Though the government declines to name these countries, and some people on the list come from such countries as Indonesia, the Phillipines and Malaysia, ${ }^{129}$ "officials [say] that most of the 5,000 names had Middle Eastern con-

127. The number ultimately turned out to be 4,793. Naftali Bendavid, Ashcroft: U.S. to Interview 3,000 More Arab Nationals, CHI. TRIB., Mar. 21, 2002, available at $2002 \mathrm{WL}$ 2635995.

128. Jodi Wilgoren, Officials Racing to Interview 5,000 U.S. Immigrants, N.Y. TIMEs, reprinted in Houston Chronicle, Nov. 15, 2001, available at 2001 WL 23643444. "Only those who traveled from nations that have been way stations for terrorists in Osama bin Laden's al-Qaeda network were placed on the list," according to Mindy Tucker, a Justice Department spokesperson. She also noted that " [w]e looked at the country they entered from, we're not looking at their nationality.'” Karen Gullo, Agencies Check Students, Visitors from Muslim Nations; List of 5,000 Men Prompts Civil Rights Concerns, THE Record (N.J.), Nov. 14, 2001, available at 2001 WL 5277814.

129. Gross \& Livingston, supra note 3, at 1419 n.22. The authors comment that these countries "do not fit any definition of the term 'Middle Eastern' (itself a vague geographical description)." 
nections."130 The government develops a substantial list of questions to ask each interviewee, covering such topics as their reasons for visiting the United States; their past travel elsewhere, including to Afghanistan; their " $[k]$ nowledge of events of September 11" and their reaction to these events; their "[i]nvolvement in terrorism" or knowledge of others' involvement; and their own, or others', access to, and knowledge of, weapons. ${ }^{131}$ As the first round of interviews is completed, the government announces a second phase, targeting 3000 people who have entered the country more recently. ${ }^{132}$

I treat this program as an instance of domestic law enforcement (domestic law enforcement targeting an international problem, namely terrorism), rather than immigration and border control, because that is how it was framed. No doubt aliens can be required, as a

130. Wilgoren, supra note 128. Gross and Livingston refer to the "acknowledged fact that the interview list is composed primarily of Muslim men from the Middle East." Gross \& Livingston, supra note 3, at 1419 n.22. For indications of which countries our government sees as having al Qaeda activity, see supra note 61. Professor David Cole has commented that " $[\mathrm{t}]$ his is as close as you get to ethnic profiling without literally relying on ethnicity," Gullo, supra note 128. Attorney General Ashcroft, however, insisted that "[t] hese individuals were selected because they fit the criteria of persons who might have knowledge of foreign-based terrorists," and "not . . . in order to single out a particular ethnic or religious group, or to suggest that one ethnic or religious group is more prone to terrorism than another. I emphatically reject that proposition, and I want all to understand that there is no place for ethnic or religious stereotyping in this plan, or in this nation's campaign against terrorism." John Ashcroft, Memorandum for All United States Attomeys [and] All Members of the Anti-Terrorism Task Forces, on "Interviews Regarding International Terrorism" (Nov. 9, 2001), available at http://www.usdoj.gov/ag/readingroom/ terroism 1.htm (last visited Aug. 5, 2002).

131. National Immigration Law Center, Justice Dept. Announces Plan to Interview 5,000 Men, Immigrants' Richts Update (Dec. 20, 2001), available at http://www.nilc.org/ immlawpolicy/arrestdet/ad040.htm (last visited Aug. 5, 2002). Some of these questions may have been dropped, at least if local law enforcement authorities who were being asked to assist in the interviews found them objectionable. See Maxine Bernstein, Terrorism Questions Meet Legal Challenges, ThE Oregonian, Nov. 27, 2001, available at 2001 WL 3624739 .

132. Attorney General Ashcroft stated that "I think in large measure these will be men who come from a variety of settings and whose passports reflect a variety of settings where there have been strong al Qaeda presences." U.S. Department of Justice Altomey General John D. Ashcroft Eastern District of Virginia/Interview Project Results Announcement (Mar. 20, 2002), available at http://usinfo.state.gov/topical/pol/terror/02032002.htm (last visited Aug. 5, 2002) [hereinafter Ashcroft Announcement]. The second round interviewees may be as old as 46 . Bendavid, supra note 127. 
condition of admission to this country, to agree to various forms of reporting to, and monitoring by, the government. So far as I am aware, however, the government has not asserted that the thousands of people in this group had actually given any prior consent to be subject to anti-terrorism interviewing; on the contrary, the government has maintained that people on the list are free to refuse to be interviewed. All of this is not to say that this program is improper, but only that it should be evaluated as a domestic law enforcement step rather than as an exercise of immigration power. ${ }^{133}$

Seen as an exercise of domestic law enforcement authority, this program is flawed. This is not because the degree of intrusion on individuals is out of proportion to the public need. To be sure, this program did not, so far as we know, respond to any particular reports of imminent peril, or to any particular information on the likely knowledge that those interviewed would have, and so it is fair to say that the public need here is probably less than in the other examples we have considered. ${ }^{134}$

But the degree of intrusion on constitutional rights was also less. The interviews were not, at least not officially, compulsory; they involved no involuntary stop and no compelled search or seizure. It is no breach of constitutional or other rights for a law enforcement agency to invite someone to schedule an appointment for an interview and

133. Before evaluating it, we should consider a question of categorization. Samuel Gross and Debra Livingston draw a distinction between programs that rest on the assumption that people of a given demographic background are likely to be criminals which they define as profiling - and those that rest only on the assumption that people of a given demographic background fit the description of a particular criminal suspect. See Gross \& Livingston, supra note 3, at 1415. Using this distinction, they conclude that it is impossible to be certain whether the interview program is based on true profiling or instead on information about criminal suspects from "an ongoing conspiracy of indeterminate size." Id. at 1420-21. They emphasize, however, that sweeping and aggressive targeting of supposed suspects on the basis of race can certainly be an "offensive and unjustified use of race" even if it is not "profiling." Id. at 1436. I argue below that this program does reflect generalizations about Arab and Muslim communities that suggest the presence of profiling. For further discussion of the definitional issues, see supra note 4.

134. Attorney General Ashcroft, describing the interview program on November 9, 2001, wrote that our continuing concern about new terrorist attacks "was heightened by the commencement of military action against the forces of Osama bin Laden and the Taliban in Afghanistan, and it was underscored by my October 29, 2001, announcement that the government had received credible information of an impending terrorist attack." Ashcroft, supra note 130. At least with the benefit of hindsight, it seems that this information did not reflect an actual imminent attack; moreover, the interview program went on for months after this warning and so could not really be considered a response to an emergency throughout its operations. 
then to answer questions put to him in a non-custodial setting. It is especially no breach if the potential interviewees know that they are free not to schedule the interviews at all. ${ }^{135}$ This image of voluntary choice is, no doubt, much exaggerated. Many people contacted by the government, especially those reached in person rather than by letter, may have felt great pressure to consent to the interviews - but anyone approached by the police is likely to feel pressure to cooperate, as Samuel Gross and Debra Livingston emphasize. ${ }^{136}$ The interviews themselves, as Gross and Livingston also emphasize, could be conducted in a courteous or coercive fashion. ${ }^{137}$ In fact, apparently very few people have overtly refused to be interviewed, and it is not clear whether the substantial number of people who were never found were evading the government or had simply returned to their home countries before the program ever got under way. ${ }^{138}$ News reports seem to indicate that the interviews themselves were low-key. ${ }^{139}$ Even though the program envisioned potential legal action against any interviewees who were found to have immigration status problems, ${ }^{140}$ in fact very few people wound up in such difficulties. ${ }^{141}$ Many interviewees, according to the

135. Attorney General Ashcroft, asked about "mechanisms that can further encourage cooperation" with the program by people "who decline to be interviewed," stated that "that's not something that has been a part of this program." Ashcroft Announcement, supra note 132.

136. Gross \& Livingston, supra note 3, at 1424.

137. Id. at $1436-37$.

138. "Of the 4,793 individuals the Justice Department originally sought, many could not be located and investigators could not even tell whether they were still in the United States. As a result, less than half - 2,261 people - were interviewed." Bendavid, supra note 127. Attorney General Ashcroft stated that "a very small number ... . declined to be interviewed." Ashcroft Announcement, supra note 132.

139. See Gross \& Livingston, supra note 3, at 1438 n.92; Bendavid, supra note 127 (quoting Hussein Ibish of the American-Arab Anti-Discrimination Committee, who said that "[i] n many ways, the program was carried out as smoothly as we could have hoped under the circumstances"); Pat Schneider, Feds Start Questioning UW Students, The CAPITAL TIMEs (Madison, Wisconsin), Dec. 5, 2001 (reporting the "non-threatening tone" seen in Detroit interviews, but also reporting that two or three Madison students had "characterized the interviews as 'scary, unnerving, anxiety-provoking'"); Terril Yue Jones, Mixed Revietus on Anti-Terror Interview Plan; Michigan: Many of the Men Sought Most from Arab Countries - Never Responded. Officials Say Program Serves Purpose, L.A. Times, Feb. 3, 2002, at A14, available at 2002 WL 2451209 (noting, however, that "some [interviewees] have reported being asked questions they thought were irrelevant and too personal, such as what they talked about in phone conversations with family members overseas").

140. See Jones, supra note 139.

141. Bendavid, supra note 127 ("a handful of the interviewees were arrested and charged with immigration violations or other offenses; none of them had ties to terrorism"). 
government, volunteered their help in the process, for example as translators for others' interviews. ${ }^{142}$

If the program was not a disproportionate intrusion, however, it is far from clear that it was an effective investigatory tactic. If the program was truly voluntary, one would not expect that those who harbored important knowledge of terrorist threats would have chosen to appear. Non-appearance, to be sure, might be significant. Its significance would have been somewhat diluted, however, by the uncertainty about whether those not appearing were still in the country at all, and by the possibility that those who ducked the interviews were frightened for reasons having nothing to do with terrorism (for example, because they had overstayed their visas). ${ }^{143}$

Even now that the first round is complete, it is difficult to assess its success in eliciting information. A Justice Department report indicates that " $[\mathrm{m}]$ ost of the interviewees gave no information relating to terrorists . . . but some provided leads that could help in the investigation." 144 This report was "edited for security reasons," 145 and so it is possible that more was learned than has been revealed; on the other hand, it has also been suggested that if the interviews had been more productive, the government would have touted that fact. ${ }^{146}$ Assuming that the number of leads elicited is in fact small, it is still difficult to say whether the program was valuable or not. Every piece of information may help, and investigations can be very difficult. ${ }^{147}$ Perhaps some of

142. Ashcroft Announcement, supra note 132.

143. For an example of an immigration attorney who "has advised clients with expired visas to decline the interviews but to seek to clear up their status," see Jones, supra note 139 .

144. Bendavid, supra note 127.

145. Id.

146. For skeptical appraisals of this program's results, see Larry Margasak, US Seeks Voluntary Terror Interviews, AP ONLINE, Mar. 21, 2002, available at 2002 WL 17186609 (quoting James Zogby, president of the Arab American Institute, saying that "[1]aw enforcement officials and local community leaders alike have made it clear to us that the first round of interviews produced no useful information"); Jim McGee, Fighting Terror with Databases; Domestic Intelligence Plans Stir Concerm, WASH. POST, Feb. 16, 2002, available at 2002 WL 13818159 (reporting that "some FBI officials view the earlier interview project as a waste of time unlikely to produce evidence against al Qaeda”).

147. In the words of an interim U.S. Attorney in Wisconsin, Grant Johnson, "If you get one or two good pieces of information out of the entire 5,000 interviews, it's worth it." Andy Hall, UW Police Will Not Question Foreigners; They Refuse to Participate in U.S. Justice Department Effort Involving Voluntary Interviews, WISC. ST. J., Dec. 7, 2001, available at 2001 WL 255323570. U.S. Assistant Attorney General Michael Chertoff has testified before Congress that "[i]n many ways, it's more difficult than looking for the proverbial needle in a haystack, because in this instance, the needle comes in disguise, disguised as a stalk of hay." McGee, supra note 146. 
the terrorism arrests in recent months owe something to these painstaking interviews, but it does appear that many of the people arrested would not actually have been among those interviewed or sought for interviewing in these programs. ${ }^{148}$ At the same time, the fact that something was learned is far from a demonstration that this was the most productive technique that investigators could have used. One must wonder, at least, whether quiet, individualized, case-by-case, person-byperson inquiry would not have been more effective than this highly publicized sweep through the Middle Eastern student population.

What seems to me to make this program most problematic is its impact on the Middle Eastern community in this country. There is no doubt that these interviews have been deeply resented. ${ }^{149}$ Though Attorney General Ashcroft contended that "the process of reaching out to foreign nationals and their communities fostered new trust between law enforcement and these communities," 150 and it does seem possible that the meetings government officials had with community groups improved communications, ${ }^{151}$ Ashcroft's portrayal also prompted sharp

148. The interview programs were directed against noncitizens. Those arrested recently in cases growing out of Buffalo, Seattle, and Portland, as well as the head of an Islamic charity recently indicted, have all been U.S. citizens. See Philip Shenon \& David Johnston, Seeking Terrorist Plots, the F.B.I. Is Tracking Hundreds of Muslims, N.Y. TImes, Oct. 6, 2002, at 1, 24 ("six Americans of Yemeni descent" from Buffalo area); Timothy Egan, The Seattle Suspect: Riddle in Seattle: Is Man Held by U.S. a Terrorist or Just a Hustler?, N.Y. Times, Oct. 6, 2002, at 24 (James Ujaama, an African-American); Eric Lichtblau, 4 in U.S. Charged in Post-9/11 Plan to Join Al Qaeda; Arrests Made in Oregon; U.S. Citizens Tried to Travel to Afghanistan to Support 'Jihad, 'Officials Say, N.Y. TimEs, Oct. 5, 2002, at A1 (all four people arrested were native-born Americans; another American was still at large; one non-citizen was also at large, but he was a permanent resident of the U.S., who presumably would not have been targeted by the interview program and in any event has not been in the United States since October 2001); Eric Lichtblau, U.S. Indicts Head of Islamic Charity in Qaeda Financing; Seen as Bin Laden Front; Prosecutors in Chicago Bring Sweeping Charges Against A Syrian-Born Citizen, N.Y. TIMEs, Oct. 10, 2002, at A1 (indictment of Enaam M. Arnaout, a naturalized U.S. citizen). Three other people from Detroit who have recently been indicted are not citizens, but they have been held in detention since shortly after the September 11 attacks and so would not have been the focus of the interview program either. Danny Hakim, The Detroit Connection: Informer Is Ciled as the Key To Unlocking a Terrorist Cell, N.Y. Times, Aug. 30, 2002, at A10 (a fourth man indicted was still at large; the source of the information leading to these indictments was a fifth person, also arrested in September 2001).

149. See supra note 85.

150. Ashcroft Announcement, supra note 132.

151. Ashcroft discusses these meetings, $i d$. A Michigan representative of the American-Arab Anti-Discrimination Committee has expressed the view "that the interviews had improved communication between law enforcement and Arab Americans." David Shepardson, U.S. Seeks More Arab Interviews, The Detrort News, Mar. 21, 2002, available at 2002 WL 14871687. 
criticism. The publisher of an Arab American newspaper responded, "What he was trying to say is, 'We humiliate them, and then they like us.'" 152

No one can be happy about causing such pain, but it is certainly possible to argue that the difficult work of investigation justifies this impact. ${ }^{153}$ It is striking, however, that even though this program explicitly intrudes on constitutional rights less than the airport or building searches discussed above, it may well be more stigmatizing. Like the random searches of Muslims on the streets that I discussed earlier, this program represents the government's highly public assertion that any member of a large group of people - not all Muslims, here, but apparently all young, male visitors from countries that are predominantly Muslim and Arab - may turn out to have information about terrorist threats, and that all of them deserve more law enforcement attention than other groups of people. There are no random inquiries of nonMiddle Easterners to lessen the appearance, and reality, that this group has been singled out.

In addition, the government's appraisal of the first round of interviews adds a new, and worrisome, rationale going beyond the search for information. In the words of Attorney General Ashcroft:

In addition to developing leads and sources of information, these interviews were designed to disrupt potential terrorist activities. The sheer volume of activity and the dedication of the task forces ensured that potential terrorists hiding in our communities knew that law enforcement was on the job in their neighborhoods.

Such a climate could cause would-be terrorists to scale back, to delay, or to abandon their plans altogether. While it's impossible to gauge definitively, this disruption is a critical component of our prevention strategy and that may well have contributed to the fact that we have not suffered a substantial terrorist attack since September the 11 th of last year. ${ }^{154}$

From one perspective, these comments merely describe vigilant law enforcement. But these comments are also troubling. They suggest that there are "neighborhoods" in which potential terrorists are hid-

152. Id. (quoting Osama Siblani, of the Arab American News in Dearborn, Michigan).

153. Samuel Gross and Debra Livingston take this view. Gross \& Livingston, supra note 3 , at 1437 .

154. Ashcroft Announcement, supra note 132. 
ing; it is hard not to think that these neighborhoods would often be Arab American neighborhoods. Alternatively, if the word "neighborhood" is metaphorical rather than geographical, then it would seem to refer to communities of predominantly Arab and Muslim visitors to the United States, within which, again, terrorists seek to hide. The interview programs seek to deprive terrorists of the ability to shelter within these communities. "Even if the terrorist had not confided his plans to anyone, he could not be sure whether his activities had generated suspicion in his community." 155 There is certainly no implication that the members of these communities in general support terrorism - Attorney General Ashcroft's comments on community reactions to the interviews convey the opposite impression ${ }^{156}$ - but there is an implication that in these communities terrorists and people who may know something about terrorism are to be found. There is also an implication that terrorists can hide in these communities successfully, unless the community's members are checked with, one by one, to elicit what they may know. All of this, it seems to me, adds a flavor of generalization about the Arab and Muslim communities in this country to a program that already potentially stigmatized them. In this way, I fear that it resonates with the public's tendency to stereotypical - not baseless, but stereotypical - response to these minorities in our society. Given this concern, and given the grounds for doubting that the actual investigative results have been substantial, I suggest that this program is unjustifiable discrimination. ${ }^{157}$

155. Shepardson, supra note 151 (quoting the Justice Department's "Final Report on Interview Project").

156. See supra text accompanying note 150 .

157. Whether this program is, on these grounds, also unconstitutional is a somewhat different question, one whose answer depends in part on whether discrimination based on the country from which a person arrived should receive stringent scrutiny. I have argued that this program is in effect a program targeting people based on their national origin, but "in effect" is not the same as "by design," and so it is quite possible that this aspect of the program would trigger only lower-level constitutional scrutiny. In any event, I have evaluated the interview program as a "domestic" law enforcement program. It is clear that current law leaves much greater leeway for such discrimination in controlling our borders. See supra note 17 . There are, however, a number of programs that fall somewhere between "border" and "domestic" law enforcement. An important current example is the "Absconder Apprehension Initiative"; this program responds to the fact that approximately 314,000 people under final orders of removal have illegally evaded enforcement of these orders. "While the INS will ultimately undertake to deport all 314,000 from the United States, there are several thousand among that group who come from countries in which there has been Al Qaeda terrorist presence or activity. We want to focus our initial efforts on these priority absconders." Memorandum for Commissioner, INS, et al., from Deputy Attorney General, Subject: Guidance for Absconder Apprehension Initiative, Jan. 25, 2002, at 1, available at http://news.findlaw.com 
The upshot of these observations is significant, but incomplete. The answer to the question, "Is racial, religious or gender profiling

/hdocs/docs/doj/abscndr012502mem.pdf (last visited Nov. 13, 2002). Another example is "Operation Southern Focus," which, according to the INS' Assistant Commissioner for Investigations, is "a multi-jurisdictional enforcement initiative aimed at targeting alien smuggling organizations specializing in the movement of U.S.bound aliens from countries that are of interest to the national security of the United States." Joseph R. Greene, Testimony before the House Judiciary Subcommittee on Immigration and Claims (June 19, 2002), available at 2002 WL 20318295, at 3. Under current law, at any rate, it seems likely the Supreme Court would be extremely skeptical of selective enforcement defenses against these programs. See Reno v. American-Arab AntiDiscrimination Committee, 525 U.S. 471, 488-92 (1999).

A related question is whether the immigration laws in general should be enforced with special rigor against citizens of particular countries not just when they arrive at the border, but even after their admission. In the immediate aftermath of September 11, it appears that many Muslim immigrants were arrested and then subjected to sometimes very prolonged detention, during which their names have often not been released. "But as it turns out, most of these cases [referring to 600 cases designated for closed-door hearings in immigration court] involved Arab and Muslim men who were detained in fairly haphazard ways, for example at traffic stops or through tips from suspicious neighbors. Law enforcement officials have acknowledged that only a few of these detainees had any significant information about possible terrorists." Adam Liptak, Neil A. Lewis \& Benjamin Weiser, After Sept. 11, a Legal Battle on the Limits of Cizil Liberty, N.Y. TIMES, Aug. 4, 2002, at 1, 20. See Cole, supra note 17, at 960-65 (discussing "secret preventive detention" after September 11th); Matthew Brzezinski, Hady Hassan Omar's Detention, N.Y. Times MAc., Oct. 27, 2002, at 50. It is possible to justify, or at least to understand, these arrests at the time they were made, assuming that each was based on probable cause, despite the fact that they may have targeted people on the basis of racial or religious profiling - on the ground that the immediate aftermath of the September 11 attacks represented a national crisis in which panicky, but understandable, steps seemed necessary. But we are not in the immediate aftermath now, and the case for continued secrecy, in particular, seems increasingly weak. Compare Detroit Free Press v. Ashcroft, 2002 U.S. App. LEXIS 17646 (6th Cir. 2002) (disapproving across the board closure of "special interest" immigration cases) with North Jersey Media Group, Inc. v. Ashcroft, 2002 U.S. App. LEXIS 21032 (3d Cir. 2002) (upholding closure). More generally, the prospect of our wielding the massive, often arbitrary (and increasingly rigorous) apparatus of immigration enforcement against entire categories of people whom we have already admitted to the country after finding that we have no basis to believe they are our adversaries, based only on their national origin or religion, strikes me as a mistake. Such a program would not be well calibrated to find our adversaries, and would surely impose much human suffering as people passed through its machinery. Cf. Sadiq Reza, Editorial, A Trap for Middle Easterm Visitors, WASH. Post, Jan. 10, 2003, at A21 (calling the government's post-September 11 scrutiny of this group "understandable", but urging the government to promise not to use information obtained in this process "to prosecute them for routine immigration violations and criminal charges not related to terrorism"). 
constitutional as a response to terrorism?" is "yes, sometimes." To say yes at all is painful, yet I believe necessary. To determine the correct definition of "sometimes" will remain a matter for skeptical and complex assessment in light of the many relevant circumstances that will bear on and shape the programs we may undertake. We have stepped out on to a slippery slope; we must now do all we can not to slide down it. 